Article

\title{
Forging Political Cadres for Re-Peasantization: Escuela de Acción Campesina (Spain)
}

\author{
David Gallar-Hernández
}

Citation: Gallar-Hernández, D.

Forging Political Cadres for Re-Peasantization: Escuela de Acción Campesina (Spain). Sustainability 2021 13, 4061. https://doi.org/10.3390/ su13074061

Academic Editor: Sean Clark

Received: 6 March 2021

Accepted: 2 April 2021

Published: 6 April 202

Publisher's Note: MDPI stays neutral with regard to jurisdictional claims in published maps and institutional affiliations.

Copyright: (C) 2021 by the author. Licensee MDPI, Basel, Switzerland This article is an open access article distributed under the terms and conditions of the Creative Commons Attribution (CC BY) license (https:/ / creativecommons.org/licenses/by/ $4.0 /)$.
Sociology and Peasant Studies Institute (ISEC), Department of Social Sciences-Sociology, University of Cordoba, 14071 Cordoba, Spain; david.gallar@uco.es; Tel.: +34-9572-18541

\begin{abstract}
Bolstering the political formation of agrarian organizations has become a priority for La Vía Campesina and the Food Sovereignty Movement. This paper addresses the Spanish case study of the Escuela de Acción Campesina (EAC)—(Peasant Action School), which is a tool for political formation in the Global North in which the philosophical and pedagogical principles of the "peasant pedagogies" of the Training Schools proposed by La Vía Campesina are put into practice within an agrarian organization in Spain and in alliance with the rest of the Spanish Food Sovereignty Movement. The study was carried out over the course of the 10 years of activist research, spanning the entire process for the construction and development of the EAC. Employing an ethnographic methodology, information was collected through participant observation, ethnographic interviews, a participatory workshop, and reviews of internal documents. The paper presents the context in which the EAC arose, its pedagogical dynamics, the structure and the ideological contents implemented for the training of new cadres, and how there are three key areas in the training process: (1) the strengthening of collective union and peasant identity, (2) training in the "peasant" ideological proposal, and (3) the integration of students as new cadres into the organizations' structures. It is concluded that the EAC is a useful tool in the ideological re-peasantization process of these organizations.
\end{abstract}

Keywords: political subjects; peasant pedagogies; agroecological peasantry; food sovereignty

\section{Introduction}

The advances made in the educational strategy of La Vía Campesina (LVC) have been addressed in depth from a theoretical perspective, and, especially, through the analysis of its experiences in Latin America. However, political formation processes within peasant organizations in the countries of the Global North are less common, and there is scant analysis of them [1-4]. This article analyzes the pedagogical practices of a political education initiative run for 10 years at an agricultural organization in Spain: the Escuela de Acción Campesina (EAC) (Peasant Action School).

The aim of this study is to analyze how, through the EAC, the principles of peasant pedagogies are applied to the formation of the cadres of Spanish agrarian organizations in the process of ideological re-peasantization. In sociological and political terms, cadres are understood to be a small group, or an individual member of such a group, of influential people that lead and train a larger organizational structure committed to achieving a certain political goal [5]. This study is framed within the material and ideological re-peasantization processes of agricultural organizations at the international level as a result of the food sovereignty proposal built by LVC as a tool to advance a more sustainable production and agri-food model. One of the key tools in these re-peasantization processes is the development of training programs for young farmers in order for them to lead the new union agendas and strategies in the different territories. In this regard, questions such as the following arise: what was the context that allowed for the creation of a forum for peasant political formation such as the EAC? What are the pedagogical dynamics that are 
implemented for the training of new cadres? What is the contents of this re-peasantization proposal? What are the main elements that reinforce the ideological re-peasantization of the new cadres and of the agrarian organizations themselves? This study analyzes the EAC's experience as a process for ideological re-peasantization and the formation of cadres through peasant pedagogies.

In order to answer these research questions, in the next section, a literature review is provided on the framework in which the food sovereignty proposal, re-peasantization by peasant organizations, and the Food Sovereignty Movement (FSM), are carried out; secondly, it examines the literature on the political formation processes at the LVC and the definition of the principles of "peasant pedagogies"; and, finally, a theoretical interpretation is offered from a Gramscian perspective of the processes for the training of cadres to strengthen collective political subjects. The next section presents the methodological aspects of the study. The fourth section presents, in its first part, the origins of the EAC, its objectives, contents, structure, and pedagogical elements; and it ends with an in-depth analysis of the key pedagogical elements in the process for the training of young peasant cadres: (1) the construction and strengthening of a collective identity, (2) training in the ideological proposal of food sovereignty, and (3) incorporation into the union organizational structure. The text ends with a Conclusions section.

\section{Literature Review: Political Formation and the Ideological Re-Peasantization of the Peasant Movement}

The concept of food sovereignty has become the reference point and unifying concept of a vision antagonistic to the current scenario in which the dominant, globalized agrifood system prevails, which is conceptualized as a "corporate food regime" [6] or as "Food Empires" [7]; "Empire" is understood as a heuristic concept to characterize the new "superstructures" of globalizing markets: "A grammar or set of rules contained within the coherent complex of scientific knowledge, engineering practices, production process technologies, product characteristics, business interests, production and control cycles, financial engineering, expansion patterns, and ways of defining problems, all this embedded in institutions and infrastructures" [7] (p. 23). That is, a dominant mode of ordering the agri-food system that feeds, and is nourished by, corporate and large-scale capitalist agriculture, and that increasingly controls production, processing, distribution, and consumption processes.

The counter-hegemonic principle generated and espoused by the LVC has been that of food sovereignty, which is a concept that arose from the peasant organizations themselves in response to the diagnosis and solutions proposed by the Food and Agriculture Organization (FAO) and its Food Security Committee on ensuring personal access to food ("Food security exists when all people at all times have physical, social and economic access to sufficient, safe and nutritious food to meet their dietary needs and food preferences for an active and healthy life" [8] (p. 5)). Food sovereignty, for its part, places peasants as the central collective political meta-subject destined to produce and provide food to society ("Food sovereignty gives us the hope and power to preserve, recover and build on our food producing knowledge and capacity. Food sovereignty is the right of peoples to healthy and culturally appropriate food produced through ecologically sound and sustainable methods, and their right to define their own food and agriculture systems" [9] (p. 1)), defying the corporate food regime's agri-food model, its territorial impacts, and its ideological framework [9-12].

LVC was established as a transnational movement that brings together peasant organizations around the world under the ideological umbrella of food sovereignty and the condemnation of and resistance to the hegemonic model of the agri-food system $[13,14]$. In turn, within the concept of food sovereignty is that of agroecology, which is understood as a practical tool for the sustainable agrarian management of natural resources, but it is also understood as "political agroecology": authentic counter-hegemonic resistance insofar as it involves questioning agronomic practices, the relationships of power between actors, the scientific model, and the dominant socioeconomic indicators of progress used by the 
corporate food regime [2,15-17]. Agroecology has been linked to food sovereignty as a tool for autonomy, sustainability, and peasant resistance to the commodification of land, seeds, water, knowledge, technology, and market dominance, considering the need to develop practices on more sustainable farms, territories, and agri-food systems [18,19].

Peasantry constitutes the material and ideological vehicle of counter-hegemonic social change in the advancement of food sovereignty, which is ascribed to the peasantry's agroecological practices and values, both in production and politics, while peasant agrarian organizations constitute essential elements for the political defense of food sovereignty. Under the concept of food sovereignty, peasants are (re)signified and attributed multiple meanings associated with the defense of territories, agroecological practices, small-scale production, local markets, the non-commodification of natural resources, resistance and struggle for access to land, the defense of ancestral seeds, the protection of common goods, sustainable production, and appropriate science and technologies $[19,20]$. The notion of "agroecological peasantry" is developed around that of food sovereignty [9-12], and processes for productive and cultural "re-peasantization" are promoted, both in peasant organizations and within the collective political narrative of the Food Sovereignty Movement (FSM) [21].

Thus, the FSM, with its different actors (social movements, Alternative Food Networks, NGOs, and the academic world), despite tensions in coordination between the peasant bloc and the rest of the actors, shares the objective of re-peasantization and the need to further strengthen and develop peasant agroecology and raise awareness among producers and peasant organizations [14,21,22].

Re-peasantization, sensu lato, may be understood as "the defense of the peasant principle" and as "a multifaceted repudiation of Empire" [7]. Re-peasantization can be understood as the process through which agriculture is restructured as peasant agriculture; it may also refer to a quantitative increase in the number of peasants [7]. Re-peasantization, through the "peasant principle", is a struggle for autonomy among farmers and peasants in the management of natural resources and in the defense and development of cooperative strategies; it is a process to augment levels of social-ecological autonomy, maintaining the logic of co-production and intensification based on their own resources, without harming them [7]. Therefore, it is a question of boosting levels of "peasantism" in management styles, and the spreading of agroecological practices, but also of instilling a sense of identity and pride in what it means to be a peasant, as a model of popular "good sense" [23], and of the resistance and the defense of territories under the umbrella of food sovereignty. Faced with material and cultural "de-agrarization", LVC and the FSM propose the repeasantization of practices and narrative frameworks, redefining and upholding anew the "peasant" and "peasantry", and placing them in the agrarian and cultural-political arena, in a Gramscian sense of the struggle for hegemony [23].

However, it is true that this commitment to agroecology within LVC has not been an easy, rapid, or complete decision, as within peasant organizations and among their producers, in many cases, agroecology is not practiced in the field or firmly defended within the ideological framework of the organizations themselves, at least at the local level [3]. This is due to the diversity of situations and contexts in which the producers find themselves, the pressures to which they are subjected to survive within the market and its logics, and the technical/agronomic and socio-political difficulties faced by the agroecological transition [14]. In other words, LVC organizations and producers directly confront agroecological difficulties such as massification, scaling out, and scaling up [19].

Precisely because of these difficulties, even before the LVC arose, the peasant organizations of each territory, particularly in Latin America [17,24], made an enormous effort to conduct training in agroecological practices among their people, especially through Peasant to Peasant processes [25], and also to bolster their own political awareness (as an organization, and its cadres and members) to confront and generate a territorial alternative to the local impacts of the Green Revolution and the corporate food regime's globalized 
agri-food system [6,7]. The development of their own training tools was recognized as vital for their organic strengthening.

In order to fortify and establish themselves as a collective political subject, the different peasant organizations over the last 50 years have generated their own tools for the training and dissemination of agroecological practices, aiming to introduce, expand, and promote a more in-depth understanding of agroecological content in their producers, and also to enhance their awareness [20,24-27]. In this regard, peasant organizations belonging to LVC acquired experience developing their own educational "tools" [10,12], spaces, methodologies, and pedagogical and organizational principles. The formation experiences have not been limited to scaling up agroecological practices but rather have also included political content and processes, particularly ones dedicated to the formation of young people, to prepare their own activists and cadres [10-12,24,26].

LVC, embracing the principle of autonomy, has generated its own instruments that meet its needs and bolster both technical and political skills, with a view to territories' collective mobilization and defense [17]. To this end, LVC proposed that Training Schools of activists and cadres be built in all territories:

The training is part of the organization. The training school should be a meeting place for the dissemination of political ideas and the foundational principles of the organization, ones that strengthen and orient the political praxis of the militants and leaders as builders of the organization. [20] (p. 177)

We must continue to accelerate political, ideological, organizational, and technical training based on our own concepts, since we know that conventional education suppresses our identity and our ideas. Such training is crucial for our movements to create new and committed actors to forge our own destiny. [13]

Thus, we find everything from the agroecology schools of different levels and in different parts of the world $[3,28]$ to the most prominent experiences in Latin America: whether it is the work carried out by the Movimento dos Trabalhadores Rurais Sem Terra (MST), with its consistently Freirian approach to awareness and its rural education work [29-31]; or those entities at the higher education level, which might be called "peasant universities", the IALAs (Latin American Institutes of Agroecology) and other schools of "political formation for organizations' grassroots leadership", including the CLOC-LVC (Florestán Fernandes National School, Andean School, Southern Cone School, Egidio Brunetto School, and the Francisco Morazán International Peasant School; in addition to the Continental School of Rural Women, and the Continental Youth Camps) [32].

Education has been understood as a key tool in processes of social change and an essential need to strengthen collective and individual awareness processes through which to confront the corporate food regime and develop alternatives, both materially and symbolically, constructing a comprehensive counter-hegemonic ideology [11-14]. These schools not only teach theoretical-practical content on agronomic and ideological issues, but all of them also try to nurture a sense of collective responsibility amongst young people toward their organizations and territories [17,26,33,34].

The educational processes of the LVC organizations are based on the premise that agroecological training must be complemented by training processes of cadres within organizations-especially young people who embrace the principles of agroecology and food sovereignty and become, therefore, agents promoting agroecological practices and the struggle to defend the territory against the impacts of industrial agriculture, which is promoted by the corporate food regime and its plundering neoliberalism $[18,19]$. In short, they are called upon to become "organic intellectuals" ("Intellectuals" should be understood as not [only] those forming part of that stratum commonly referred to with this designation, but, in general, the entire social mass that exercises organizational functions in the broad sense, in both the field of production and culture, as well as in the administrative-political sphere" [23] (p. 103) (Author's own translation)) who embody the 
"agroecological peasantry", the collective identity, and the ideological principle of food sovereignty [11,12,24,33-36].

Therefore, it is understood from a Gramscian perspective that subaltern groups generate their own strata of intellectuals committed to organizing, mobilizing, and consolidating political interpretations supporting the interpretation and political action of the subaltern group itself $[23,33,34]$.

This formation is considered profoundly organic because it integrates the training processes of young cadres into the daily functioning of organizations, promoting active participation and the assumption of responsibilities in their territories and at their own organizations, as new active members learn what is like to be a cadre in practice and how one proceeds $[17,26,34]$.

Then, these are training programs that guarantee and nurture generational change within organizations, as the histories and legacies of organizations and territories are preserved through the transmission of knowledge from the older leaders, who share their knowledge and experiences [35]. Thus, the objective of these training processes is, together with the challenge of re-peasantization, the dialectical challenge of getting young people to "become movement", and getting the agrarian movement to "become young" [12] (p. 14).

To achieve these objectives, LVC, through its organizations' different actions, has developed a set of political-pedagogical resources reflecting the strategic nature of political formation and its ties to peasant struggles, the need to proceed based upon peasants' social practices, and theoretical/practical work in different spaces and with different approaches to training, which are rooted in a commitment to comprehensiveness, openness, and plurality, with training centers focused on food sovereignty [20] (p. 176).

Proceeding based on popular education, especially the theoretical and methodological teachings of educator Paulo Freire, who conceives of popular education as a pedagogy of the oppressed [30,31], peasant organizations have developed their own philosophicalpedagogical principles (Table 1), with references even being made to an "emerging and diverse peasant pedagogy" [37,38] and an "agroecological peasant pedagogy" [39] or socialization spaces based on the "epistemes of the peasantry" [10,38,40]. The principles of these peasant pedagogies are based on the diálogo de saberes ("dialogue among different knowledges and ways of knowing" [40] (p. 1)), pluriepistemology, training in all dimensions of agroecology (technical-agronomic and political-cultural) and dynamizing leaders and facilitators of political processes promoting agroecological and political transition in the territories and the organic nature of the training [38] (p. 15). Organicity makes it possible to exercise new capacities of human relationships, political management, and the collective construction of educational processes through the exercise of direct democracy, protagonisms, participation, and commitment in the decision-making, distribution, and performance of tasks. The students, through organicity, engage in part of the political, social, productive, and pedagogical construction of the school and/or institute itself [17] (p. 5).

Table 1. Philosophical and pedagogical principles of La Vía Campesina (LVC).

\begin{tabular}{|c|c|c|c|}
\hline $\begin{array}{l}\text { Philosophical principles of } \\
\text { the Latin American } \\
\text { Agroecological Institutes [41] }\end{array}$ & $\begin{array}{l}\text { Pedagogical principles of the } \\
\text { Latin American } \\
\text { Agroecological Institutes [41] }\end{array}$ & $\begin{array}{l}\text { Pedagogical principles of training } \\
\text { Via Campesina in Central Americ }\end{array}$ & $\begin{array}{l}\text { The pillars of a transformative } \\
\text { agroecology learning approach [2] }\end{array}$ \\
\hline $\begin{array}{l}\text { Education through and for } \\
\text { social transformation } \\
\text { Education through and for } \\
\text { diversity } \\
\text { Education through and for } \\
\text { work and cooperation } \\
\text { Education through and for } \\
\text { rebellion }\end{array}$ & $\begin{array}{c}\text { Practice-theory-practice } \\
\text { Teaching-learning } \\
\text { Dialogue among ways of } \\
\text { knowing } \\
\text { Action-based, participatory, } \\
\text { and contextualized research }\end{array}$ & $\begin{array}{c}\text { Sharing Misticas } \\
\text { Learning by doing } \\
\text { Unlearning in order to learn } \\
\text { Wisdom dialogue } \\
\text { Problematize power relations } \\
\text { Starting from and returning to experience } \\
\text { Valuing diversity } \\
\text { Relearn, reteach }\end{array}$ & $\begin{array}{c}\text { Wisdom dialogues } \\
\text { Horizontal learning } \\
\text { Combining the practical and the } \\
\text { political } \\
\text { Building multi-scale social } \\
\text { movement networks/Builds and } \\
\text { strengthens networks / Building } \\
\text { social movement networks }\end{array}$ \\
\hline
\end{tabular}

Source: Compiled by author based on $[2,35,41]$. 
As part of peasant and popular pedagogies, the principles of the "pedagogy of alternation" [33,42,43] are included as an essential part, in which the knowledge worked on during "Study Times" must be verified and applied to the particular realities of each student during "Community Times". Thus, each student conducts an "investigation" into their own reality (their family, their home, their community, their territory) in which they develop the theoretical-methodological skills worked on in the training, while these are enriched by the complexities of daily life in their own environments. At the same time, these "investigations" are shared with the rest of the students and educators in an ongoing process of action-reflection-action for social transformation and the liberation of the oppressed classes. Then, these are elements of liberating education that are applicable to both agronomic and political issues, and they feature learning through action, sharing and fostering curiosity and discovery, combining theory and practice, problematizing reality, and always returning to the action-reflection-action sequence, valuing and upholding peasant, indigenous, and popular knowledge; it is a popular education that upholds what Gramsci [23] characterized as the "good sense" of popular cultures: common sense not alienated by hegemony but rather "autonomous" common sense derived from their belonging to subaltern and oppressed classes.

These processes of training and their "peasant pedagogies" also include particular attention to the symbolic, favoring immersion in a collective identity full of meanings and reminiscences of previous struggles, and recognizing the importance of forming part of a global movement and its organizations, struggles, and territories. In this regard, the Místicas are the culminating moments of territorial and organic peasant identity in its struggle for the defense of food sovereignty. The Misticas can be defined as self-managed collective actions with which LVC events begin and/or conclude, in which, through the use of the flags of peasant organizations, and elements of peasant culture (seeds, tools, food, books, etc.), music, dance, or theater, the power of the peasant struggle and its link to the territories and Mother Earth are transmitted in an emotional and artistic way. "The Mística is where we express our collective values, not as a theoretical topic, but rather through other means and experiential forms. Sometimes we say that it is doing theater, but this is not the objective. Rather, what we do serves to bolster and give a new impulse to our political motivations, to dream of a better world, of the utopia that we want to develop, as part of an ideal world, one of respect, of collective construction. Representing day-to-day actions, challenges, alternatives, solutions... And for this, we need to organize our expression and our dreams, which have to do with our living and our doing" [44].

At the same time, relationships with colleagues at other organizations, and also educators at other groups, or even other types of FSM actors, help to generate trust and for people to feel part of a broader food movement in which the relationships between different actors of the FSM must be strengthened, identifying themselves as "historical/political actors" in struggles for food sovereignty $[2,33]$.

In short, in view of the LVC's educational policy, it is found that from a Gramscian perspective, training is understood as an instrument vital to processes of social change as well as essential to strengthen collective and individual awareness processes and build alternatives, both materially and symbolically, developing a comprehensive counter-hegemonic ideological proposal-in this case, food sovereignty $[23,30,33,45]$. Therefore, this training is oriented toward the cadres as part of the structure of collective political subjects.

All these experiences have in common the "organic" nature $[23,45]$ of the training of cadres to bolster peasant organizations and augment their impact on their territories and the strengthening of the transnational agrarian movements [14]. In this regard, "organicity" is understood as the collective process for the establishment of a shared political identity and the construction and defense of an ideological cause that, through an organizational structure (a union or a political party, for example), struggles in the social and political arenas for the redefinition of hegemony $[23,45,46]$. That is, these experiences can be framed in accordance with a Gramscian interpretation of the development of collective political subjects, of how subaltern social groups organize and build their own mechanisms of 
political and cultural strengthening to grapple with the ideological and material pressure exerted by the dominant classes.

In this case, proceeding based on an extensive sociological and political discussion we use the following definition of a collective political subject. This definition takes elements from different authors and sociological currents-among others, from Marx [47], Gramsci [23], Thompson [48], Appadurai [49], Mannheim [50], Anderson [51], Hobsbawn and Ranger [52], Freire [30], Hardt and Negri [53], Laclau and Mouffe [46], and Scott [54], and other debates in sociology and political anthropology. To consult the theoretical discussion on this definition, see Gallar [55], Gallar and Acosta [56], and Gallar and Calle [57]. It is understood as a heuristic tool to analyze and understand the consistency and maturity of a social subject with a view to becoming a relevant political subject. Its function is to verify the state of constitution and maturity of a political subject but not to assess its contents and forms. We will understand a collective political subject to be a category or group of people that (1) shares some sociological characteristics or attributes, and engages in and implements a series of common social practices, (2) is recognized as a "we" vis-a-vis a "them"; that is, a group that develops and assumes a collective sociocultural identity; (3) is constituted in the form of some type of organization or dynamic providing for stable cooperation: a political and organizational structure or apparatus that supports and coordinates sociopolitical action; (4) has its own ideological proposal: a normative proposal on their socioeconomic and cultural duty; (5) possesses a forum for reflection for the training and development of "organic intellectuals": spaces and processes that serve to provide content, interpret, and channel the political proposals of members and/or the structure; (6) has a repertoire of political action, advocacy, and protest adapted to its needs; (7) has a social base, which is understood as the support, affiliation, or sympathy of part of the population it claims to represent; (8) generates some type of appeal to the common good as opposed to corporative demands and interests, offering for this an expanded "we", an inclusive and intersectional proposal for a socially expanded collective identity; and (9) has a strategy of social and political coordination with other related actors and different and unconnected ones; and one to thwart opposing groups.

Thus, based on this definition, engaging in a preliminary exercise at the international level with the global peasantry related to the LVC, we can recognize a collective peasant political subject insofar as they (1) are small farmers, of family and territorial agriculture, who feel affected by the corporate food regime, (2) make an effort to strengthen themselves by consolidating and reinforcing their collective peasant identity through the intensive and continuous use of flags, kerchiefs, and other symbols, and performing Misticas at all their meetings, (3) participate in the organizations that make up LVC, (4) recognize and defend the ideological framework of food sovereignty and agroecology, in this regard opposing the "corporate food regime" and "food empires", (5) reinforce their apparatuses and structures through the training of peasant cadres, holding technical training activities through peasant-to-peasant training dynamics, and others; and organize ideological and awareness-raising activities, (6) possess and develop a training, protest, and consolidated political advocacy policy, (7) promote internal diversity (in terms of the productive sector, territory, sociocultural identity, and gender) in their organizations, and open their activities up to other peasants not affiliated with the organizations, managing for them to, in some way, feel represented by LVC and the food sovereignty proposal, (8) expand and uphold the right of peoples and individuals to adequate food, and call for agriculture and food production to embrace social and collective objectives, such as ending hunger, protecting rural communities, offering healthy and high-quality food to consumers, and combating climate change, (9) have extended their alliance generation strategies by sharing and codeveloping the concept of Food Sovereignty with the rest of the FSM, and supporting and strengthening the strategies for the construction of relocated and sustainable agri-food systems.

Therefore, this article analyzes how the pedagogical principles of the "peasant political proposal", food sovereignty, and political agroecology are implemented in the development 
of a training institution for young people who are called upon to become new cadres of a renovated and rejuvenated agrarian movement. In particular, and in accordance with the focus of the principles of "peasant pedagogy", the elements related to the construction and consolidation of a union- and peasant-based collective identity (1) are analyzed in depth below, with training revolving around the content of the ideological proposal of food sovereignty $(3,7)$ and its implementation within an organizational structure $(2,4)$.

In short, these training spaces can be understood and analyzed as basic tools and processes when it comes to training young people who are to become leaders and cadres within the organizations representing peasants as a collective political subject as well as organic intellectuals of the peasant movement and agroecological peasantry [10,11,26,33-35].

\section{Materials and Methods}

This study examines the EAC as an exceptional and pioneering case study [58] in the current Spanish peasant movement, allowing for analytical and interpretive dialogue with the rest of the political formation processes at the international level within LVC. In Spain, it would be necessary to go back to the political formation experiences of the Peasant Schools in the 1970s and 1980s, and today, this case is only comparable to the "Baserritik Mundura" [1] experience in the Basque Country. As explained in the following section, the EAC is a state-wide project with a ten-year history reflecting the evolution of the movement for Spanish food sovereignty, achieving coordination between different actors of said movement, and engaging the main union organization of the Spanish agrarian movement.

This work forms part of the process behind systematizing the EAC's experience. The author, as an active member of the Spanish FSM and having been involved in the EAC's work, has participated in all phases of the process for the constitution of the EAC, from 2010 to the present: from the design period (2010-2013) to the development of the five course programs completed $(2014,2015,2016,2017-2018$, and 2019-2020). He has participated in different roles, having been a member of the consortium as a representative of the ISEC (Institute for Peasant Sociology and Studies) and a pedagogical coordinator of the EAC, where he was responsible in each course for one of the modules featuring EAC content. He also tutored several students in each edition. The author has participated in all the consortium's meetings, most of the EAC's educational conferences, and in all the teaching staff meetings.

Along with this diversity of roles, the author has complemented his participation from a position as a researcher, conducting ethnographic research [59] based on his total access to the social field, and the opportunity to conduct participant observations with all the people and in all the places and contexts making up the EAC. This dual role as a researcher and participant was accepted by all the EAC's parties, as the researcher was responsible for the drafting of systematization reports and the development of different evaluation tools.

This ethnographic research was carried out through field work (see Appendix AFieldwork Table) which involved the following: (1) participant observation in different places and contexts of the EAC (consortium, coordination, and teaching staff meetings; symposia, tutorials); (2) ethnographic interviews [59,60], individual and group, with members of the consortium, coordinators, teachers, and students; (3) a participatory workshop for collective reflection (see Appendix B), (4) the revision of internal documents, and (5) the preparation of evaluation and systematization reports. Throughout the text interview, citations are identified according to their position in the EAC's structure and the year of the interview.

During the participant observation, work was done using a field diary, photographs were taken, and audio recordings were done of various phases of the encounters. The information collected through the different research techniques was constantly analyzed in accord with the EAC's systematization needs. The generation of evaluation and systematization reports served during the research process as an exercise in triangulation and reflexivity [59] with the different actors of the EAC's structure. 
For this article, the main categories of analysis were (1) the development of collective identity, (2) training in contents, and (3) integration into organizational structures.

\section{The EAC as a Tool of Re-Peasantization}

As activists for a thriving rural world, we need to make training a key tool to ensure the presence of critical, continuous activity by active supporters, especially young people, in all the different social organizations and movements, especially those peasant organizations that believe that another world is possible, and necessary, and that it must take peasants into full and careful account.

We need to train a new set of peasant leaders at organizations; people who fully accept and delve into the struggle for a thriving rural world where peasants come first. We need to train young people who undertake commitments within organizations, with renewed resolve, to shake up and disrupt internal realities. We are a political school dedicated to strengthening peasant leadership. Our aim is to facilitate, as far as possible, the inner rebirth of leaders who will play key roles and do so in a democratic way. [61] (p. 16)

\subsection{The Origins of the EAC}

Basically, the EAC is a political training program adhering to the principles of the LVC's educational policy for the formation of young cadres of agrarian organizations belonging to the LVC. At the EAC, there have occasionally been some students not linked to other non-agricultural organizations of the consortium, such as Colectivos de Acción Solidaria (CAS), but practically, the entire structure of the EAC revolves around agricultural organizations, especially the COAG, the coordinator of organizations of small and medium familiar farmers. In the first two years, the Sindicato de Obreros del Campo-Sindicato Andaluz de Trabajadores (SOC-SAT) also participated. The SOC-SAT is the union of agricultural laborers in Andalusia, whose defense of agrarian reform has been a fundamental model to be followed in the last 40 years, boasting an enormous capacity for mobilization and protest, and achieving very important successes, including the appropriation of the properties of large landowners and the constitution of agricultural cooperatives to generate rural employment. Its principles include agroecology, although its effective incorporation into cooperatives is limited. The CNA (National Confederation of Agriculture) of Portugal, a member of LVC, has also participated in the last two courses.

Then, the EAC is comprised of Spanish agrarian organizations that are members of the LVC, with a major role being played by the family farmers' coordination organizations COAG [62] and its youth section, Juventudes Agrarias (JJAA) [63], or Agrarian Youth; and other Spanish FSM organizations endorsing the diagnosis shared by all the parties that agrarian organizations (fundamentally, the COAG) need to "re-peasantize" more to continue supporting the FSM. Although it is understood that the agroecological transition and re-peasantization on farms are fundamental elements, the EAC conceives of itself as a forum for political formation, but without the capacity to provide technical-agronomic training for the on-farm transition.

Therefore, this school is fundamentally aimed at the ideological re-peasantization of COAG, which harbors as keys principles the defense of a social and professional model of family agriculture, and a model of territorial agriculture based on small- and medium-sized production. As a coordinating organization, COAG is made up of Territorial Units (TUs), which have total autonomy. Due to the productive and socioeconomic peculiarities of Spain's different territories, COAG is characterized by a high degree of heterogeneity within it. Calls for fairer prices, and the defense of the viability of professional family farming in a thriving rural sphere are the main themes of its political advocacy work vis-a-vis the Spanish Government, and the European Union's Common Agricultural Policy (CAP); but, under the umbrella of professional family agriculture, different perspectives on the production model and adaptations to the pressures of the corporate regime are accommodated. Thus, debates on intensification, the technological model, the territorial model, organic production, climate change, generational change, and the role of women 
in the sector and inside organizations, and others, are issues that elicit diverse responses from the different TUs. Hence, COAG, at the state level, must accept them, managing this diversity and these internal tensions. In addition, COAG, at the state level, is a member of LVC and supports the food sovereignty movement. However, the political pressure brought to bear by its TUs is primarily aimed at the corporate defense of better prices and a CAP that benefits professional family farming.

As part of this organizational autonomy, the strategic action lines of the EHNE (Basque Farmers Union) [64] and the Sindicato Labrego Galego (SLG) (Galician Peasants Union) [65] - members of COAG and also member organizations, directly, of LVC-include a marked commitment to food sovereignty, though without entirely abandoning the framework of professional family farming. In both cases, although as organizations, they endorse approaches and strategic orientations supporting food sovereignty and agroecology, they are saddled with the contradiction that most of their members' practices are not, in fact, agroecological. Nevertheless, in both cases, they participate in LVC's international forums supporting food sovereignty. Regarding re-peasantization, especially in the case of the EHNE, there has been a process of strategic orientation toward agroecological training and the incorporation of young people into the agrarian sector as baserritarras ("Peasants" in Basque) through a strategy of production diversification, agroecological management, direct sales, and coordination with consumer groups. Meanwhile, EHNE has maintained and strengthened its alliances in the area of food sovereignty, supporting the LVC in a prominent way (even hosting the VII LVC Conference). On the territorial side, it has supported the Etxalde movement as a collective forum for the defense of food sovereignty $[4,66]$. Etxalde is a broad social movement led by baserritarras in Euskal Herria, founded in 2011: "Etxalde is made up of baserritarras and is open to people linked to agriculture. The implementation of food sovereignty in the Basque Country through agricultural activity is its central objective. It also seeks to promote strategic alliances with social and union movements for the development of food sovereignty, both locally and internationally" [67] (p. 1).

Given this agrarian context, with a diagnosis shared by all the parties, and the desire to bolster the re-peasantization of these organizations, the creation of a Political Training School, such as that proposed by LVC, was promoted. This is a school that would not have been possible without the context of a burgeoning FSM and its surging confidence, coordination, and collective strength. From the agrarian organizations, the state COAG participates as an effective member of LVC at the international level, and it created the ARCo (Agriculture of Shared Responsibility: A Project for the Creation of Short Marketing Channels in Accord with the Concepts of Agroecology and Food Sovereignty [68]); EHNE and SLG contributed great energy and an effective re-peasantization message, assisting in the promotion of Territorial Alliances for Food Sovereignty, which continued to strengthen alternative food networks. Other areas of action also emerged, such as access to land (agrarian parks and land banks, platforms for the defense of fertile soil, etc.), and campaigns supporting the search for alliances with consumers through health, condemning the agroindustrial model; in addition to the coordination processes between the agroecological movement and municipalism (through the Network of Cities for Agroecology, working for urban food policies). All this is framed in a context impacted by the energy transmitted by the Nyelení Food Sovereignty Forums (2007 and 2015), the optimism generated by the possibility of influencing the international agenda, and the international narrative promoted by a prominent LVC and its alliances, advancing the concepts of food sovereignty and agroecology. Finally, the FSM looked forward to the EHNE's important hosting of the VII LVC Conference (2017). FSM enjoys trust thanks to more than 20 years of joint work along with Plataforma Rural on campaigns critical of the CAP, the success of protests against transgenics in 2010, and celebration, as activists, of the international days recognizing peasants' struggle. This is a framework that capitalizes on the collective consensus coinciding on the importance of strengthening peasants as a political subject, fomented for more than 20 years by the Plataforma Rural's (for more information on 
peasant lines of discourse, see $[55,56])$ pro-peasant discourse and the LVC's mandate on political education.

"Plataforma Rural-Alianzas por un mundo rural vivo" (PR) (Rural Platform-Alliances for a Thriving Rural World) is a collaborative platform created in 1992 by different actors of what would later become the FSM ("Plataforma Rural, a forum for meeting and convergence (allowing the collective work of various organizations, farmers, environmentalists, social action activists, consumers, social workers, etc.) ( ... ) To analyze, propose and design collective work strategies that favor a vital rural sphere ( . . . ) making society see that the problem of agriculture and food is not limited to the sector; rather, it is a problem that affects all citizens" [69]), and that has served as a forum channeling a confluence of different sensibilities to advance an agricultural model and a society that is committed to food sovereignty, to agroecology as a production model, the rights of the peasantry, a dignified and vital rural world, and the vindication of "social and solidary peasant values" as part of a political movement defying the corporate food regime (WTO, GMO, mega-exploitation, extractivism, etc.) and striving for a new and fairer CAP. Plataforma Rural was a precocious forum of convergence that, before LVC was constituted, and before the concept of food sovereignty had been defined, was already championing the defense of the rural sphere and stressing the importance of addressing its peasants as a central political element. In this sense, PR has served to defend and construct the narrative about the "agroecological peasantry" as a political subject, establishing itself as a platform for the "convergence in diversity" necessary for regime change [22,70], and managing to coordinate actors and sensibilities related to a "thriving rural world" and food sovereignty.

Then, the EAC stemmed from the Plataforma Rural (The team promoting it forms part of the Universidad Rural Paulo Freire (URPF)), responding to the mandate of the Nyelení Forum 2007 to enhance political education processes. Thus, in 2010, the first proposal for a School of Agroecology and Peasant Action was made, although it would not be until 2013 that the opportunity to implement it was found, taking advantage of COAG's receptivity and funding potential by some of the PR's non-agrarian organizations: Mundubat and VSF-Justicia Alimentaria, the development NGOs harboring a new perspective of SouthNorth cooperation and subscribing to the food sovereignty paradigm; Amigos de la Tierra (Friends of the Earth), an environmental entity backing the food sovereignty movement; Colectivos de Acción Solidaria (CAS), an NGO of rural development associations that employs approaches defending the value of peasantry and a thriving rural world; the Institute of Sociology and Peasant Studies (ISEC) at the University of Cordoba, an international leader in committed research on political agroecology; and the Universidad Rural Paulo Freire (URPF), a project for the recovery and promotion of peasant knowledge as an instrument for rural development and food sovereignty, emerging from the Plataforma Rural and CAS [53]; in other words, the EAC was formed as the result of a whole set of coordination and collaboration efforts between different FSM actors involved in collective vitalization and re-peasantization.

"At Amigos de la Tierra (Friends of the Earth), we are clear on the fact that work must be done on both sides, on consumption but also on production, in rural areas, to provide support so that more farmers are dedicated to agroecology and producing in a more sustainable way. We understand that peasant organizations must be strong in this to lend assistance and get their members to, increasingly, view ecological issues as something normal. But not only the ecological aspect, but for everyone to believe in food sovereignty and commit to agroecology". (Friends of the Earth_Consortium_2014)

"We support the Agroecology Schools and the IALAs in Latin America, so when we got this proposal here in Spain, we saw it clearly". (ConsortiumMundubat_2015)

This is how the EAC Consortium came about; it is made up of organizations contributing resources to the creation of the EAC: COAG and its Juventudes Agrarias (Agrarian 
Youth of COAG), EHNE, Mundubat, URPF, Amigos de la Tierra, ISEC, CAS, and VSF-JA. It became the political-pedagogical committee at which decisions are made and objectives, contents, and pedagogical principles are defined.

“This Consortium's creation is important, because this is where support for this project is demonstrated, providing aid with concrete resources and thinking collectively about how to tackle this challenge of getting all local organizations to strongly embrace food sovereignty, which is not easy". (ConsortiumCOAG_2015)

\subsection{Objectives and Contents of the EAC}

The EAC bases its work on a pedagogical plan setting forth its specific and strategic objectives, principles, and methodological references, and a series of competencies and instrumental objectives (Table 2). Throughout this pedagogical project, the pro-peasant narrative articulated by Plataforma Rural is maintained and reinforced, and it is embraced by the consortium as its content and prevailing line of discourse. The EAC emphasizes the process for the re-peasantization of the TUs through the training of a new generation of cadres to whom the baton is to be passed in the different territories. This challenge was initially tackled through the coordination of the state COAG, and from there, it was transferred to the local unions, an effort being made to involve them so that they could participate by sending students from their territories, and for the local unions themselves to make a commitment to this process of political formation and generational change.

"We see it in our local unions, we are always the same and getting older: we must make way for young people and let them come with fresh and strong ideas about this issue of food sovereignty. We have to attract young people to the union, and there need to be young people who participate, who take the reins". (Consortium-COAG_2017)

Table 2. Strategic objectives and instrumental competencies.

\begin{tabular}{l} 
"Specific and Strategic" Objectives \\
\hline Link training to the strategic and political projects of social movements and organizations, especially peasant organizations \\
participating in the School of Agroecology and Peasant Action. \\
Always take as a reference point the social practices of the peasantry, valuing its set of autonomous knowledge and capacities. \\
Promote generational renewal within social organizations and movements that are fighting for a thriving rural world and for food \\
sovereignty, especially in peasant organizations. \\
Comprehensive formation that encompasses all the people's different dimensions and needs. \\
Training that incorporates open political thinking in response to diversity. \\
Training that does not simply inform the student, but rather seeks ways to enhance his awareness and promote social \\
transformation with a view to emancipation.
\end{tabular}

Instrumental Competencies and Objectives

Defend with political and economic arguments the Food Sovereignty Movement, the peasantry, and its logic

Leadership and invigoration capacity in the organization and in the rural sphere

The ability to invigorate groups and participation and organization forums with horizontal values

The ability to recognize and uphold the value of peasant knowledge and resources

The capacity to use various participatory tools and methodologies for the diagnosis of the territory, with a special stress on capturing the demands of the territory's various actors

The ability to take note of the demands of various groups and collectives and turn them into dynamic and transforming initiatives. An attitude of empathy and sensitivity toward peasant and rural culture

Source: [61] (pp. 17-18).

It is noteworthy that the EAC's objectives do not include technical/agronomic training in agroecological management and practices but rather refer exclusively to political formation within the framework of food sovereignty. The very structure of the training, the resources available, and the objectives of the consortium made the EAC focus on broader 
training for "new peasant leaders in organizations, who take on and fully live the essence of the struggle for a living rural and peasant world" [61] (p. 16):

"The EAC is not a course in organic agriculture. It is something else. You have to talk about many things when you talk about food sovereignty, or the peasant cause (...) Agroecology has to be there, but the EAC cannot and does not want to be an agroecology course". (Consortium-EHNE_2018)

"Agroecology will have to reach the territories, it will be necessary to make the change from agriculture to agroecology, when possible, but that is something that will come slowly, and specific courses will have to be offered for that. But first the local unions have to see the general idea". (Consortium-COAG_2016)

"As CAS, we see that agroecology is very important, but the rural environment is not only about agriculture, we have to look at the rural world with a broader perspective". (Consortium-CAS_2015)

The contents are organized into six modules addressing different issues related to the new lines of discourse and practices stressing the need for unionism integrated into the FSM's work (Table 3). These contents were decided via consensus between the members of the consortium and the coordinators of the EAC, and they were later developed by the team of teachers. For each of these modules, the faculty drafted some brief reading material and made complementary materials available to students. These contents are worked on throughout the course in each of the four weekend encounters that each course consists of, in which, approximately every two months, all the students and most of the teaching staff meet. At each encounter, there are one or two modules that serve as a thematic foundation through which the teaching staff clarifies the contents and dynamics to work on at those meetings.

Table 3. Escuela de Acción Campesina (EAC) contents modules.

1. Food: the international sociopolitical context

2. Popular education tools and methodologies

3. The peasant proposal

4. A look at agrarian history and its social movements

5. The feminist peasant proposal

6. Actors and social dynamics in the rural world

Source: [61] (pp. 20-21).

Therefore, these contents maintain the peasant-centered line of discourse and content as an ideological proposal, rendering the training more in-depth through a narrative about the importance of the peasant and agrarian organizations and touching on content less common for members of the agrarian world and local unions, such as the question of peasant agroecology as a form of production and a commercialization alternative, feminism in rural areas, and broadening viewpoints on the rural beyond just the agrarian.

"Including the gender and feminist perspective was a necessity, and [it] constitutes a real shock for many of the students, because they are not used to it, because the agrarian world is still a very masculine one, and it is hard for them to put on those feminist lenses, to shed 'normal' views existing in the rural world and among the producers". (Teacher responsible for the Feminism Module_2017)

"I think this Module [Actors and Dynamics in the Rural Sphere] is important, to include issues that affect towns and the people who live there, who may or may not be farmers: the issue of aging, the loss of health or education services, the issue of the integration of immigrants ... , because this business about 'emptied Spain' encompasses many things and is not just about farmers". (Teacher in the Actors and Dynamics in the Rural Sphere Module_2017) 


\subsection{Structure and Pedagogical Elements}

The EAC's organizational structure (Table 4) is made up of the political-pedagogical consortium, a coordinating body, the teaching staff, the students, and the political heads of the Territorial Units (TUs) participating in each edition of the EAC. The coordination, carried out by members of Universidad Rural Paulo Freire (URPF) and COAG, is charged with mediating between the rest of the EAC's elements and serving as a nexus of union between the consortium and the EAC's functioning, in addition to serving as a direct link with the TUs, to support the faculty and serve as a resource meeting students' possible needs. In turn, the teaching staff is charged with preparing the specific content and work dynamics at each meeting.

Table 4. EAC structure.

\section{Profiles Tasks and Responsibilities}

They define the objectives, contents, and pedagogical principles

Consortium Representatives of the organizations

They choose the coordinators and the teaching staff

They approve the groups of students proposed by the TUs

Nexus of union and communication between the consortium and the development of the EAC

Coordination

People from Plataforma Rural and close to COAG, with trust and demonstrated legitimacy
Relationship with the TUs: explanation of the EAC and assistance by the organizational heads of TUs Teaching staff support

EAC ambassador for the students

\section{Organizational Heads of TUs}

Political and organizational leaders of the TUs
They define the objectives and contents of the EAC to be incorporated by the TUs and how to integrate the students into the TUs' organic structure They supervise work on the Peasant Action Plans

FSM activists with experience and training in pedagogical processes

The teaching staff People trusted by the consortium A diversity of education, experience, territories, and organizations

Young (under 35) Farmers

Students Members related to or from the TUs' environments

Diversity of profiles: productive models and sectors, territory, age, gender parity
They implement the contents and design the training activities

They supervise the Peasant Action Plans

Source: Compiled by author.

In the EAC's five classes (2014, 2015, 2016, 2017-2018, and 2019-2020), more than 70 students participated, from practically all across Spain. Almost all of them came from COAG Territorial Unions settings, although there were some Sindicato de Obreros del Campo-Sindicato Andaluz de Trabajadores (SOC-SAT, Agricultural Workers UnionAndalusian Workers Union) students in the first years and some CAS (Colectivos de Acción Solidaria) students. In addition, in the last two editions, a guest student attended from the Confederação Nacional da Agricultura (CNA), which is a Portuguese agrarian organization belonging to the $\mathrm{LVC}$, as a result of the CNA's interest in replicating the EAC in Portugal.

The EAC is a school without a fixed location, and it is not limited to study in the classroom. Each EAC course brings together approximately 20 students from about 10 TUs, lasts around 10 months, and consists of two complementary instruments that are alternated: first, four weekend encounters, at which the contents and skills are worked on through various activities; and Peasant Action Plans, which each student must draw up. 
The Peasant Action Plans consist of some type of intervention at the local organization and/or in the territory decided on by the TU in order to strengthen the organization itself in its internal functioning or in its relationship with the territory (new affiliations, dissemination and communication of trade unionism, etc.). Therefore, these Peasant Action Plans are not individual choices by the student, but rather a decision by the TU itself to strengthen it through the training of the young person in whom they have placed their trust. Then, the Peasant Action Plan is an educational instrument featuring the "pedagogical triad" made up of the student, the teacher, and the head of the TU. In this pedagogical triad, the head of the TU takes on a commitment to the EAC to assist the student with their Peasant Action Plan and to integrate the intervention and its lessons into the strategic lines of the TU, as well as to incorporate the student into the organization itself in active roles, or even positions of responsibility. Meanwhile, the student, who must have been previously involved in the TU, is charged with developing and putting into practice the TU's proposal and carrying out the diagnosis and/or the corresponding actions to respond to the TU's needs and requests. Finally, the teacher, a member of the teaching staff, is tasked with furnishing the Peasant Action Plan to which the students and his TU are committed with thematic and, especially, methodological support (Table 5). In this way, the Peasant Action Plan can include several students from the same TU to tackle the task proposed by the TL. It is in the Peasant Action Plans where the configuration of the "pedagogical triad" comes to full fruition as an organic process of the TU, supporting the student's training through a framework of activism and learning through action.

"It was difficult for us to define it well, but we already [at the end of the second year of EAC] realized that the Peasant Action Plans cannot be an invention, something new. Rather, it has to be something in which the student is already involved or that the union is already clear on. It should not be something to do the work for the EAC. It's not that. The student already has to be involved in it, so it is important to choose the students well. The Peasant Action Plan must also be something that does not end with the EAC course, but rather something that continues beyond it, something that reinforces the organization and continues to engage the student after the course". (EAC Coordination_2015)

"Many of us [consortium organizations] were familiar with how the IALAs and others worked, and we saw that it was important that it not be just any other course. Rather, we had to try to relate the training to what is happening in the territories, in the organizations. It was not supposed to be theoretical, but rather grounded in the concrete and the local. This is what has been attempted with the Peasant Action Plan". (Consortium-Mundubat_2018)

This work structure, combining the encounters with the Peasant Action Plans (Table 5), reproduces the model of "alternation pedagogy", which, in "peasant pedagogies" and "education in the field" $[38,42,43]$ is called "Community Time", during which the student is to apply and reflect on their daily reality in the territory and on the organization of the contents worked on in the classroom training encounters.

"The idea is for the Peasant Action Plan to be one more step for young people to get involved in the local union and gradually change things, so that they believe in it more, and feel like the future of the union". (Consortium-Juventudes Agrarias COAG_2018)

Throughout these five courses, more than 40 Peasant Action Plans have been worked on, addressing different topics: the revitalization of the youth area, the dynamization of the women's area, communication campaigns, generational renewal strategies, work with biofertilizers, direct sales strategies and short food supply chains, cooperative strategies, and the interpretation of sanitary regulations. Each of these Peasant Action Plans, according to the circumstances and strategic lines of the TUs, as we will see below, have had different impacts on the construction of union identity in the students, the integration of young people into local unions, and the political agendas of the local unions themselves. 
Table 5. Peasant Action Plans schedule.

\begin{tabular}{|c|c|c|c|c|}
\hline $\begin{array}{c}\text { Time } 0 \\
\text { (Before Encounter 1) }\end{array}$ & $\begin{array}{c}\text { Time } 1 \\
\text { (After Encounter 1) }\end{array}$ & $\begin{array}{c}\text { Time } 2 \\
\text { (After Encounter 2) }\end{array}$ & $\begin{array}{c}\text { Time } 3 \\
\text { (After Encounter 3) }\end{array}$ & $\begin{array}{c}\text { Time } 4 \\
\text { (After Encounter 4) }\end{array}$ \\
\hline $\begin{array}{l}\text { Definition and proposal } \\
\text { of the Peasant Action } \\
\text { Plan by the head of TU }\end{array}$ & Methodological Design & $\begin{array}{l}\text { Initial diagnostic } \\
\text { and/or } \\
\text { information-gathering } \\
\text { activities: meetings, } \\
\text { interviews, surveys }\end{array}$ & $\begin{array}{l}\text { Diagnostic and/or } \\
\text { action activities } \\
\text { Information sharing } \\
\text { meetings } \\
\text { Action and continuity } \\
\text { proposals } \\
\text { Systematization of } \\
\text { results. }\end{array}$ & $\begin{array}{c}\text { Continuity and } \\
\text { integration of the } \\
\text { Peasant Action Plan } \\
\text { into the TUs } \\
\text { Integration of the } \\
\text { student into the TUs }\end{array}$ \\
\hline \multirow[t]{2}{*}{$\begin{array}{l}\text { "Pedagogical triad" } \\
\text { meeting }\end{array}$} & $\begin{array}{l}\text { Head TU follow-up } \\
\text { and dialogue }\end{array}$ & $\begin{array}{l}\text { Head TU follow-up } \\
\text { and dialogue }\end{array}$ & $\begin{array}{l}\text { Head TU follow-up } \\
\text { and dialogue }\end{array}$ & $\begin{array}{l}\text { Political continuity } \\
\text { through the head TU }\end{array}$ \\
\hline & $\begin{array}{l}\text { Methodological } \\
\text { support for tutors }\end{array}$ & $\begin{array}{l}\text { Methodological } \\
\text { support for tutors }\end{array}$ & $\begin{array}{l}\text { Methodological } \\
\text { support for tutors }\end{array}$ & \\
\hline
\end{tabular}

Source: Compiled by author.

The encounters are the in-person meetings at which approximately every two months, all the students and most of the teaching staff meet. They are organized by a TU that offers itself to host it, as part of its dedication to the EAC, as one or more students in the course are members of this organization, and also because they have the financial capacity to host the group. Each EAC course includes four weekend encounters held in different parts of Spain. Each encounter is organized at different pedagogical junctures and features different educational activities through which the EAC's objectives, competencies, and contents are specifically worked on (Table 6). As we will see later, the aim of each of these activities is for students to discover content related to the "peasant proposal", discover unionism, gain a sense of union and peasant identity, and ponder how to transfer the EAC's contents and forms to their relationships with their TUs.

Table 6. "Sample" encounter activities.

\begin{tabular}{|c|c|c|}
\hline Friday & Saturday & Sunday \\
\hline & Mistica led by the students & Mística led by the students \\
\hline & $\begin{array}{l}\text { Module Activity: Specific dynamics to } \\
\text { work on the corresponding module }\end{array}$ & $\begin{array}{l}\text { Group submission of the } \\
\text { committees' work }\end{array}$ \\
\hline "Itinerant classroom" & $\begin{array}{l}\text { "Peasant Leadership": Talk/Presentation } \\
\text { by two union leaders from the territory } \\
\text { about their lives and work as they relate } \\
\text { to the struggle and union organization }\end{array}$ & Encounter evaluation \\
\hline Lunch & Lunch & Lunch \\
\hline $\begin{array}{l}\text { Welcome and presentation of the host TU } \\
\text { consortium organization presentation }\end{array}$ & Visit to experiences in the territory & "Itinerant classroom" \\
\hline \multicolumn{3}{|l|}{$\begin{array}{l}\text { Module Activity: Specific dynamics to work on the } \\
\text { corresponding module }\end{array}$} \\
\hline $\begin{array}{c}\text { Peasant Action Plan tutorials: students and } \\
\text { teachers }\end{array}$ & Committees' work & \\
\hline $\begin{array}{l}\text { "Peasant Dinner" with food brought by each } \\
\text { attendee as a sample of their crops or territory }\end{array}$ & Dinner & \\
\hline $\begin{array}{l}\text { "Peasant Colloquium": An informal collective } \\
\text { gathering centering on a topic linked to the } \\
\text { conference's modules, organized by the teaching } \\
\text { staff, the TU, and/or a consortium organization. }\end{array}$ & $\begin{array}{l}\text { "Peasant Entertainment": music, poetry, } \\
\text { or local folk dance }\end{array}$ & \\
\hline
\end{tabular}




\subsection{Forging Peasant Cadres: Organicity as a Pedagogical Principle}

In this section, the EAC's activity is interpreted in light of the principle of organicity, which is understood as the application of the construction of a collective identity around an ideological proposal through an organizational structure for the struggle for hegemony in the sociopolitical arena $[12,23,33,34,45]$.

Based on this definition, below we will show (1) how the construction and reinforcement of a collective identity within the EAC is worked on, (2) how the EAC approaches training based on the "peasant" ideological proposal, and (3) how the EAC generates and takes advantage of a framework constituting an opportunity for the incorporation of young producers as part of the process of generational renewal and the re-peasantization of local unions. Obviously, these three elements are not really independent of each other, but they will be analyzed separately to facilitate a clearer analytical interpretation. Each subsection will address (1) the role of the Peasant Action Plans, (2) the formal and informal spaces of the encounters; in addition, the (3) relationship with local unions, and (4) movement for food sovereignty in general will be briefly addressed.

\subsubsection{Collective Identity and the EAC: Building a Unionist and Peasant-Based "We"}

As stated in the quote from the EAC Educational Project with which this section began, one of the EAC's key elements is its effort to promote and strengthen a sense of belonging to agrarian unionism, a notion of peasants as a "we" with which the EAC students feel represented and with which they identify. This peasant-oriented line of discourse is a constant that permeates the entire relationship between the EAC and its students.

Firstly, being chosen as an EAC student is another step in the bolstering of union identity, as the student is exposed to the philosophy of the EAC, emphasizing that it is not just any course but rather part of the reinforcement and formation of the local union itself.

"The students who go to the EAC are chosen because they are trusted and banked on, because we want them to be the immediate future of local unions in their territories, and the future of COAG as well". (Consortium-COAG_2015)

In turn, the consortium decided that the EAC ought to strengthen and "re-peasantize" local organizations and unions, and this included the perspective that the training should be aimed exclusively at the organization's new youth, and not training the technicians who work for the organization. In other words, the EAC proceeds from a recognition that more and more tasks are being delegated to the technicians hired, who are even asked to get ideologically involved, with part of the union responsibility sometimes falling upon these technicians, due to a lack of unionists taking charge of strategic decisions.

"We cannot neglect the school with technicians and strip it of its agrarian and territorial dimension. Unionism must be led by unionists, not technicians". (EAC Coordination_2013)

In this way, the EAC students are chosen by the local unions themselves from among the young people who are most involved in the daily activities of the union, who participate in the activities, in the conferences; young people who approached union circles seeking to participate in a collective structure that defended their interests. Among these students, we can identify three profiles: (1) the children of unionists who continue with the family union tradition, (2) young farmers without a union family tradition but who join the rural sphere and adopt a combative stance, and (3) "neo-rurals", with more agroecological and peasant profiles, who trust local unions as part of left-wing agrarian unionism, or even as a reference point of La Via Campesina.

"It ran in the family with me, because my father and my uncles were with the union, and I consider UAGA my home. What I've seen is that, to defend the interests of farmers, we have to be united and organized, and that's why I'm with the UAGA and now the EAC". (Student_2015) 
"When I started out with the cows, I saw that this was very difficult, that they made it very difficult for us farmers, and that if you don't team up with others, if you don't have an organization that defends you, you're screwed. That's why I turned to UGAM, to see if it was possible to fight through it" (Student_2018)

"I believe that the future of the countryside must be agroecology, that we have to organize like La Via Campesina does and fight for food sovereignty". (Student_2018)

Therefore, the EAC students are chosen from among those who are involved in and feel part of the local unions, but the EAC has also proven to be a tool bolstering union identity in students. Through the Peasant Action Plans, the students have felt more involved in the local union, after tackling direct and concrete tasks at the local union itself, which has boosted their sense of belonging and identity.

"At first I didn't understand the Peasant Action Plans, but then I saw what it was and realized that it was something important, something that the union asked me to do, that I had to work on and do it well". (Student_2020)

"Suddenly I saw myself thinking and speaking on behalf of the union, as part of the local union itself (... ) The Peasant Action Plan forced me to take a serious position as part of the union". (Student_2018)

"I was already doing things for the local union, but the Peasant Action Plan was another step towards feeling part of the union and of assuming more responsibilities". (Student_2018)

As for the encounters, the fact that they are something in-house, bringing together young producers from each of the local unions, has constituted one of the outcomes most appreciated by the students themselves; getting together as equals has been one of the aspects most praised in the participatory evaluations carried out in each of the courses, and one of the most notable things at the systematization workshop carried out in 2017, and also in the interviews conducted. During the encounters, there are different formal and informal spaces (see Table 6) that facilitate personal exchanges between the students themselves, moments when their experiences as producers are shared; they talk about their farms and what their problems are, and they share photos of crops and animals, discuss their territories, and also their local unions.

"Here at the EAC I've met new people. At first you feel shy, but at the end of the first encounter, with the classes, the meals, after everyone goes out for a drink at night together, you realize that you share many things, even though some of us have greenhouses, and others, animals or more crops". (Student_2014)

All these forums in each of the EAC courses serve to reinforce exchanges between equals, fostering dialogue facilitated by the fact that all the students are young people, producers and involved in the union-based defense of farmers. For the students, these interactions represent a time of empowerment and reinforcement of their identity as young union farmers.

"Of course, you see yourself here with the rest of your fellow workers, who are more or less your age, and are working in the fields like you, and who believe in this about unionism, and you feel good, you feel that we're all in the same boat". (Student_2020)

Another one of the aspects most often underscored in the students' evaluations is the recognition of the enormous diversity that exists between them, but how all these differences seem to shrink when they meet up and see that they all have more or less the same problems, with production, the market, regulations, and that they all share the objective of defending farmers. Of course, these differences have also generated sharp debates and conflicts, but the general opinion is that beyond these specific conflicts, especially over the agroecological/conventional production model, they all have mutually 
enriched each other, understood each other's difficulties, learned about the main problems and trends in each territory; and that everyone, in the end, was in the EAC because they believe in agrarian unionism and the need for change.

"I see that those of us in the class, we're very different, some with cows, others with orchards, others with greenhouses ... from the south and the north ... but, at the same time, we're all here for something, because what is happening in the countryside pains us". (Student_2020)

"It is true that we have clashed because some of us are more for agroecology and ecology, and we are very clear on that, while others embrace a very conventional model based on massive plots, productivism, and, when it comes to the issue of manure, to fertilization, and everything else, well, we don't agree. But they are people who believe in it and who, despite everything, defend cooperativism, and are fighting for their regions. Another question is whether I believe that this model cannot continue, that we have to take up another one". (Student_2015)

Informal forums such as the "Itinerant Classroom", the "Peasant Dinner", "Peasant Entertainment", the "Peasant Colloquium", and the "Night Owls Classroom" (Table 6) are ideal events to foster bonds and collective identity between these young people, who have been chosen by the local unions as candidates to promote the revitalization and generational renewal of unions in their territories. "Peasant Entertainment" is an activity organized by the TU or EAC coordinators in which a local folk artist (or storyteller, dancer, etc.) is invited to share their music, stories, or dancing. Finally, "Night Owl Classrooms" is a time for students and tutors to go out to dance or have a drink, a time to strengthen group bonds, share impressions, and for the students to get to know each other by sharing their professional and life experiences, photos of their crops, territories, and their local cultures. All these gatherings reinforce the collective spirit and, as we will see later, strengthen links and facilitate communication and coordination between local unions, while supporting the work within Juventudes Agrarias. In addition, these events are deliberately designed by the structure of the EAC itself, since the peasant vision is conveyed at all of them, peasant identity is reinforced, and a sense of identity as agrarian producers and unionists is promoted. For example, at the Peasant Dinner, each attendee brings a product they produced, or one representative of their region's food culture. Before dinner, each person must share their product with the group, how it was produced, and what it means to him or her. In these explanations, a peasant line of discourse is articulated and shared collectively, expressing pride in the local, the artisanal, in that which one has produced, in the value of being producers and bringing quality food produced with pride to the collective.

"I brought my honey, we have the honeycombs in Cordoba, and we've won several awards ... Every day it's more difficult, due to the prices on the market, the issue of honey imports, and the EU labeling ... But we continue on, because we are proud to do what we do, because the people who are in the field are important. So, I hope you like it". (Student_2017)

"I have a vegetable garden, and we are working on a project to recover traditional varieties ... , we do it agroecologically, we sell with baskets and in consumer groups in Valencia, we are involved in the issue of participatory certification ... These are our little jewels". (Student_2018)

Meanwhile, at the formal meetings, work is also done to cultivate a collective identity, from the union identity perspective, both peasant and agrarian. The premier forum in this regard is the "Peasant Leadership" session, in which a man and a woman who are prominent figures in the history of union organization and the struggle of the TU host the encounter, sharing their experiences as unionists, what their personal and political careers have been like, the evolution of the union struggle, its internal and external successes and failures, their experience in union representation, how they have combined that union work with their family farms and their own families; in short, a personal account of their 
careers in union activism and struggle. Through this activity, the students receive a lot of content, ideas, and perspectives on unionism. Above all, the students benefit from these sessions because they foster a powerful sense of union identity, as they become an exercise in individual responsibility, promoting awareness of whether each one is willing to strive to continue as a union leader in the defense of the interests of their TU, and considering the effort involved in combining these new responsibilities with maintaining the activity on their farms. The questions and discussions following the speakers' remarks reveal the depth of their soul searching, the degree to which they have internalized their own concerns related to what the speakers have shared, and how they feel when putting themselves in the speakers' shoes. This exercise in the generational transmission of knowledge prompts acute reflections on their identities and enormous personal questioning of their own futures as unionists, and it transmits lessons from the historical leaders' own experiences, which each student must assimilate, interpret, and adapt to their own reality and experience.

"It was very exciting to listen to him [local unionist leader] talk about all the battles when they rolled the tractors out onto the street, about the cucumber and potato wars, when we joined the EEC. I'd heard something about it at home, but it was incredible to hear Eduardo talk about it". (Student_2014)

"I was delighted to hear from her [local unionist leader] and to realize all the fatigue that affects unionism, because these are the same doubts that I have now that I am starting to really get involved in the union. This is very hard, but it's also worth it". (Student_2015)

"That's why I asked him [local unionist leader] what his experience was like, because the same thing is happening to me with my farm: I can hardly run it because I dedicate a lot of time to this". (Student_2018)

In turn, the Mistica forums are conceived by the EAC as a reproduction of the teachings of La Via Campesina: gatherings featuring symbolic representations of peasant struggles, of the unity of peasant organizations and people, and care for nature. At the EAC, the students create the Misticas in accord with their capacities, abilities, and creative and dynamic experience, preparing a collective poem, a little skit, or a dynamic that includes turns to speak about their emotions regarding, for example, the agrarian sphere, the EAC, or peasantry. Sometimes, seeds, foods, or flags are incorporated, as at the LVC Místicas.

"I don't know if they are as beautiful as the LVCs, but here we have done what we could, and I think it was beautiful. Our group that did it, we thought about it, and we came up with this [a little skit about market pressure on producers], which conveys what we are all experiencing as producers". (Student_2020)

"It has become clear to me what a Mística is, and I think the emotional side is important, having a moment to connect with the peasant struggle, with who we are, with what we defend". (Student_2018)

The EAC, in its organizational proposal and its objectives, sets out to work not only with students, but also with local unions and their involvement through the political heads of the TU. However, the involvement of these political heads in the EAC, beyond monitoring the Peasant Action Plan, has been a challenge; sometimes because they are very busy handling the day-to-day management of the local union, and other times due to a certain lack of dedication. In this regard, the identity development work with the head of the TU involving more than the rest of the local union and its agenda was very limited.

"One of the challenges we have as EAC is to engage the head of the TU more, because in some territories they have only been able to follow the Peasant Action Plan from afar. In other territories, the TUs were more involved, especially in those cases in which they were former students of the EAC. In any case, this part was a bit weak, and many of these people are unionists who spread themselves thin, and have to be involved in everything, so they can't do it all". (EAC_Coordination 2020) 
Finally, as a result of the Consortium of FSM organizations, the EAC includes a broad perspective, and among its objectives is fortifying the link between peasant organizations and the rest of the FSM organizations. In this regard, at most of the encounters, a brief presentation is given by one of the consortium's organizations as part of the EAC's commitment to expanding and strengthening networks and helping to coordinate the peasant sector and other FSM organizations, with the idea of building a "movement of movements" [68] and forging links of "convergence from diversity" [22]. In fact, some of the consortium's organizations have organized some of the encounters, sharing part of the activities with their own territorial members. However, it seems that this coordination still has not managed to impact students through the EAC, and the development of a broader identity in terms of FSM is still a long way off.

"At some encounters, we have introduced the organization, or an activity has been carried out at the Peasant Colloquium, but the consortium and its organizations remain ethereal to EAC students". (Amigos de la Tierra-Consortium_2019)

"At the encounters or in the tutorials, the students see more clearly the role of other organizations in the world of agroecology and food sovereignty thanks to the experience of the teachers, but there is still no real link between the students and what we call the food sovereignty movement". (ConsortiumMundubat_2018)

\subsubsection{The Ideological Content of the EAC: The "Peasant" Proposal}

Another key element of the principle of organicity is the work done on the content of the ideological proposal. In this case, the EAC's ideological proposal is food sovereignty and the "peasant principle", which is developed in its "Educational Project" [61], in the contents of the modules, and in the pedagogical dynamics put into practice during the courses. In this regard, in the same way that the construction of collective identity is present in all the forums, the ideological proposal permeates all the activities of the EAC, both in the Peasant Action Plan and in the formal and informal activities of the encounters.

The Peasant Action Plans are, for the EAC, a pedagogical forum in which an effort is made to apply and internalize the EAC's ideological proposal and contents (Tables 2 and 3). This proposal stresses the importance of unionism based on the defense of farmers and is based on the re-peasantization of their discourse, practices, and organizations, seeking to apply a broad view of the rural environment (not just agrarian) and to advance a much more horizontal vision of dynamization and leadership than the most hierarchical traditional perspectives, and one incorporating a feminist perspective. However, this ideological proposal is broad and complex, so each of the students and the local unions have sought to adapt and apply some part of it to the Peasant Action Plans. The Peasant Action Plans are spaces for work on the "peasant" ideological proposal in which the "pedagogical triad" aim for the students and local unions to internalize and advance, as far as possible, toward re-peasantization. In this sense, the Peasant Action Plans are understood as an initial exercise within a much broader process both individually and at the organizational level of local unions.

"My Peasant Action Plan was about trying to identify the needs of young people and get them involved in COAG. For this I did a survey that I gave them, I've called a lot of young people, and in the end we had a meeting with quite a few people from the Juventudes Agrarias (Agrarian Youth). I realized through this that many young people don't want to get involved because they would rather do their own thing, and [they] don't understand this thing about being in a union. And it's the other way around. What I don't understand is someone not being in a union to defend his interests". (Student_2014)

"With my Peasant Action Plan, the idea was to learn how unionism works, what it means to be on a board, the positions that exist, what is done on each committee ... because those involved, inside, are clear on this, but those of us who are 
outside, we have no idea, and that also dissuades us from participating. So, the Peasant Action Plan was about doing interviews with the older people and synthesizing all these things, in order to be able to share it with the young people who want to get involved". (Student_2018)

"My Peasant Action Plan was about the participation of women in COAG; that is, about women's limited participation in COAG. With this work, I had to reflect more on why this was so, why women participate less despite being in the field just like men. And that forced me to think a lot about this. It led me to realize things, and also to talk about it with some other women whom I have surveyed or have met with". (Student_2020)

The ideological proposal is also worked on in the different phases of the encounters. One of the most obvious is the sessions linked to the content modules. Each encounter is linked to one of the content modules, so at each encounter, there are two specific moments to work on these contents (see Table 6). The objective of these dynamics is two-fold: first, students are to learn some key concepts, and what role this content plays in the union movement and in the FSM. Second, the aim is for students to incorporate the content into their knowledge and experience and learn how to convey it to their TUs. For this, the teacher in charge of this module prepares how to cover the subject: group work, discussions, analysis of a short video, or a short presentation. Normally, work is done with participatory techniques in groups, starting with the students' previous ideas and their own experiences as producers, and their relationship with trade unionism, before sharing the results and conducting a critical assessment of them, and the teacher adding content. For example, one of the joint activities between the modules on the history of unionism, feminism, and methodologies is a kind of "theater of the oppressed":

In this theater, four characters act out the process behind the changing of positions at the top of the TU. In the first version, prepared by the teaching staff with four students, a general secretary (an older male) calls a slightly younger man on the phone and they talk about the former's preferences regarding who would be the most suitable person to serve as head of political organization, and the possible hiring of a woman in the Women's Area. After this telephone conversation, a meeting is held in the office, and it is shown how the men exploit their complicity and use codes, disparaging the Women's Area. The candidate proposed plays the role of an under-empowered woman. The activity consists of analyzing the relationships of power, age, gender, and political culture in decision-making within the TUs, etc. For this, the students analyze what they saw and how it relates to practices in their daily lives and in their TUs. In this "Theater of the Oppressed" exercise, the students can join the performance, changing the roles of the previous actors, or including new characters in the scene, thereby generating a new social situation of political transformation. This is one example of how EAC works on individual and political power cultures, what union dynamics have been, what the new expectations are, how to move towards them, etc. (Field Diary_2018)

Visits to experiences in the territories of each encounter are another important forum to work on the ideological proposal. At each encounter, an afternoon is dedicated to visiting local projects representing concrete cases of the development of a peasant-friendly rural world, a "live rural world", which is one more consistent with agroecology and food sovereignty. In any case, these visits are to a range of sites: intensive greenhouses, small-scale neo-rural agroecological projects, large-scale cattle operations, farmers markets, artisans' food workshops, or projects for the social integration of immigrants in rural areas. Each visit seeks to recognize the diversity of the sector and the territories, and how each place features its own trends, limitations, and opportunities. The aim is to include all the dimensions of agroecology, addressing technical management issues, but also economic, 
social, gender, and feminist ones; decision-making, the relationship between the experience and the territory or the $\mathrm{TU}$, for example.

"I had never seen greenhouses before ... And I was impressed, because it's a completely different reality from mine. In Euskadi (Basque Country), there are many people doing organic projects, small baserris (farmsteads), or even orchards, many people making baskets, and so on. The greenhouses are another dimension, and, getting to know my colleague, I see that they are also screwed, and that it is difficult to do anything else there". (Student_2015)

"I loved each encounter's visit to each place, because we saw very different realities, and in each one of them, with the work in class, we looked at their strengths and weaknesses, the role of women, livestock issues, and others related to direct sale markets, or projects with immigrants. There's a lot to learn". (Student_2019)

When working on the ideological proposal, as of the second year, the EAC adopted committee work as a pedagogical tool. Committee work is another important pedagogical element when it comes to incorporating content and generating a sense of belonging. There are four committees (Thematic, Mistica-Logistic, Methodology, and Feminism) and the group of students is divided into four groups, which will rotate taking on the tasks of each of the committees at each of the four encounters, so each group will carry out the tasks of all the committees. The distribution of students into groups for the committees is done observing diversity: territorial, personal and productive profile, and gender. At each encounter, the Thematic, Methodology, and Feminism committees are in charge of observing and systematizing the contents, dynamics, participation guidelines, and the gender analysis. For this task, each committee has a small observation guide and the support of a teacher. The group meets at the beginning of each encounter to determine and organize the instructions. At the end of the second day, it meets so that the group can share its work with the teacher and decide what and how to share its observations with the rest of the group. This work enhances the acquisition of content, thanks to the observation guide and the fact that the group is responsible for conveying its observations to the rest of the group. The Mistica-Logistics committee is in charge of preparing the Mistica for each encounter, making it an exercise in creativity and a search for common meanings adapted to the EAC. In addition, the members of the Mistica-Logistics committee are charged with keeping the spaces clean and orderly, making sure the time frames set for the activities are observed, coordinating the preparation of the "Peasant Dinner", and waking up their peers in the morning. On the last day of each encounter, each committee reports its observations to the entire group, and the most relevant lessons learned are underscored, and/or a discussion is held on how to convey these concerns to their TUs-although sometimes, this feedback becomes a kind of evaluation of the encounter. In this regard, the committees function to carry out somewhat more in-depth work on the contents of the EAC, on how the "peasant proposal" is interpreted and applied, how it works with participatory dynamics, and how the gender and feminist perspective is applied.

"It seems to me that the committees serve to pay more attention to what is happening, to be more attentive to details. In this way you learn more. If not, maybe they're things that can happen to you because you're not used to focusing on them. Also, because we have to share the results with the rest of the group, that forces you to pay more attention and to try a little more". (Student_2020)

The testimonies of the territorial leaders, "Leaderships", is another activity in which, in addition to working on the emotional and identity factor, the ideological proposal is worked on. These testimonies convey the importance of union organization, and of organized protest, work in the territories, the need for political advocacy, etc. In the subsequent debates, the current concerns of unionism and EAC youth are discussed.

In the same way, the "Conversation Boards" are another forum for discussion and work on the ideological proposal. The "Peasant Colloquiums" are relatively informal forums following the "Peasant Dinners", at which the teaching team encourages all the 
students to meet in a casual way for an after-dinner chat. Then, a topic of interest is posed for discussion, whether from the EAC modules, any activity of the TU, or one of the consortium's activities. Thus, in an informal way, a time for dialogue is shared that reinforces the vision of the EAC as an instrument for reflection on peasant unionism and the rural world.

Finally, the Místicas are another gathering for ideological work, not just identity, in which the students must transfer and transmit, artistically and emotionally, the most ideological contents of the "peasant" proposal.

"One of the difficult things about the Mistica is trying to convey so many things at one time, to explain all those things that we are seeing at the EAC, all the things that we experience in our lives as producers ..." (Student_2017)

"I loved the Mistica that the EHNE people did because you could really understand the criticism of the agro-industrial model, how we are trapped in it, and how we can wake up and find solutions, such as agroecology and short marketing channels". (Student_2020)

As for the influence of the EAC on the narrative and the union agenda of local unions, as we will see later, the process of re-peasantization has been diverse and uneven. The analysis of the incorporation of ideological content by the political heads of TU or its application to the strategies, agendas, and narratives of local unions is beyond the objectives of this article. Even so, some examples are presented in the next section. All the parties involved in the EAC recognize that students receive basic initial training, and that this serves to introduce and strengthen the ideological proposal in the local unions, but it is also acknowledged that a single course is too little. In this regard, the students, the teachers, and the consortium have discussed the need to reinforce this training by generating a second level of the EAC in which to continue working with the students who are in positions of responsibility in COAG to bolster this process of training and re-peasantization.

"Couldn't we go on to a second course? This way we could continue training, because we still have a lot to learn! I'd also love to continue with my classmates in another course". (Student_2014)

"The work is important, but it is true that there is still much more to do, and it would be good to continue supporting and training the young people who have been through the EAC and are in executive positions. Perhaps a second level would be a good option". (Consortium-Mundubat_2019)

Finally, the food sovereignty ideological proposal is also worked on with the consortium's organizations, which have contributed to the development of the objectives and content, also contributing with a part of the teaching team and participating in some of the encounters, either organizing them jointly with their affiliates in that territory, giving a brief presentation of their objectives and activities; or by organizing a Peasant Colloquium, according to their specific lines of work. In any case, the consortium's organizations mostly feel represented and present in the contents of the EAC through the collective definition of its objectives, contents, and teaching team.

"As consortium organizations we could have a greater influence on the development of the EAC, but we believe that this is a proposal, above all, for producers, for the people of COAG, and what we are interested in is their people receiving the contents that we have all defined together, and with a teaching team that is very much part of the agroecology movement, of food sovereignty". (ConsortiumAmigos de la Tierra_2017)

\subsubsection{New Peasant Cadres}

From a theoretical framework with a Gramscian perspective and for the development of collective political subjects, the training of organic intellectuals and new social leaders 
is linked to their integration into an organizational structure; in this case, local unions, Juventudes Agrarias (Agrarian Youth), and the state COAG.

"This is not a course like any other that one signs up for: this is an effort made by the consortium to train young people from local unions to learn what LVC is, to learn the history of unionism, and that of peasant struggles, because these are things that almost no one knows about anymore, because they aren't told $\ldots$ and they have been important. The aim is for them to learn things and then put them into practice in their unions, for them to be aware of the importance of being there on the front lines and defending the rural world, the producers, and doing so with other perspectives". (EAC Coordinator_2015)

In this regard, the work through the Peasant Action Plans is a way of bolstering the relationship between the students and the local union, a way for the students to take on direct responsibilities vis-a-vis the local union, and through the specific relationship with the political head of the TU to respond to the demands of the local union, and expand the work or link between the student, the union, and the territory. For many students, the Peasant Action Plan has been the first real and concrete task that they carry out for and as a local union. This real exercise is a way for the students to integrate into the structure of the local union in a "formal" way.

"When I was encouraged to attend the EAC as a student, I was not very clear about it, but, between what the political head of the TU told me, and Juventudes Agrarias (Agrarian Youth), I was convinced, because they made me see that it was important for young people to take a step forward, and that this was to make the local union stronger". (Student_2018)

"The objective of the Peasant Action Plan was to find out why there are so few women who participate in COAG Murcia, and to create a group of women within it. I was already responsible for the Women's area, but with the Peasant Action Plan we have set it as a more concrete task". (Student_2014)

"Now that I'm involved in the Peasant Action Plan I have to meet, no matter what [with the political head of the TU], and I'm calling the young people of the region to organize a meeting with them, and also doing a survey when I call them. And all that is on behalf of COAG". (Student_2014)

"We already had an informal youth group in the union, but with my Peasant Action Plan and the one from the previous year this group has been strengthened, and now we're all more involved; also, because it is something that we've created ourselves". (Student_Galicia_2017)

In fact, through participation in the EAC and the work carried out in the Peasant Action Plan, more than half of the students in the first three courses of the EAC have gone on to occupy union positions: as heads of TU areas (Youth, Gender, Organic Agriculture), members of TU Executives, or even of the national Executive, and participants in international LVC forums. In turn, the Juventudes Agrarias organization (Agrarian Youth of COAG) has been strengthened by new groups of young people who have passed through the EAC. In some cases, where there was no autonomous Youth section, they have been established thanks to initiatives and work carried out on Peasant Action Plans. Juventudes Agrarias has also been strengthened by improving its forms of organization and communication, as efforts have been made to furnish the issues to be worked on by it with more political content, and to have a greater impact on COAG.

"Many of the students have gone on to assume positions of responsibility in local unions or beyond [Juventudes Agrarias, Plataforma Rural, international representation]. Here the movement has been twofold: they have gone to the EAC because they were going to have representation positions, and they have representation positions because they have gone to the EAC. In other words, 
the EAC is serving to reinforce the unions' internal dynamics". (ConsortiumCOAG_2015)

"[The students] have many opportunities to continue up to the Executive positions, and it is good that they have been trained here, and all together". (Consortium-COAG_2015)

However, regarding integration into positions of responsibility, the EAC finds itself, after four editions, faced with the situation that in many of the local unions the positions available for generational change have already been filled by young people and, therefore, the students of the successive years no longer have the opportunity to occupy these positions of responsibility.

"It is true that in the first courses they very quickly took the executive positions, or as thematic coordinators, because they were the most prepared and the most involved people, having been sent to the EAC at the beginning. But now it is more difficult for the best students to access executive posts, in part because that generational change has already taken place". (Consortium-Juventudes Agrarias COAG_2020)

Analyzing the impact of local unions, or COAG, as a whole, on re-peasantization would require an in-depth analysis that transcends the objectives of this text, which addresses the pedagogical processes of the peasant movement in the formation of new cadres for their local organizations. In any case, by way of example, it is worth citing some of the most visible and significant effects, such as the process of generational change on the board of COAG-Valencia, with up to three members who had been EAC students, support from other EAC students, and participation by one of the EAC teachers on the COAG Valencia technical team. This has bolstered the work, giving greater visibility and dedicating more resources to organic production and direct sales within the organization. The official name of the organization has even been changed to include the concept of peasantry; it was redubbed "Coordinadora Camperola del País Valencià". In the Sindicato Labrego Galego, a Youth Group was established to support and liaise with the youth of the region. In Aragon, generational change has also been facilitated, with one of the EAC students becoming a member of the national executive, another student replacing him as the regional executive and as the head of the state Juventudes Agrarias. In Andalusia, through some of the EAC students and some Peasant Action Plans, Juventudes Agrarias has been created and consolidated in the region. However, in other territories and local unions, the Peasant Action Plans and the involvement of students or political heads of TU have not succeeded in integrating students into management positions, nor have they generated the EAC's spirit of change. In any case, the evaluation of the impacts on the re-peasantization of organizations must be the object of a specific analysis that falls beyond the scope of this paper.

"With the EAC, many local organizations have been reached that now want more EAC, and that's not easy (...) The objective of the EAC is not to change the COAG. Rather, the COAG will change when many people have been trained. It's about introducing provocative issues that generate questioning". (ConsortiumCOAG_2016)

As for the EAC's students, or even the local unions themselves, integrating and coordinating with other actors in the movement for food sovereignty, it seems that the EAC has not made much progress. Rather, in those cases in which there were already previous collaborations in the territory between the local union and one of the organizations, or when the local union was more involved in the FSM, the EAC has enhanced communications, but in the rest of the cases, new approaches and collaboration have not been achieved.

"It would be important, and it was one of the objectives, to foster alliances between the local unions and the territorial organizations of the consortium's organizations, but yes, we are still far from that". (Consortium-Mundubat_2019) 
"In Valencia there was a very good previous relationship between some people from COAG and the Platform for Food Sovereignty, and that shows in everything that is happening. The change in COAG Valencia also stems from there, because they are people who have not only been with COAG, but they're very into all this about agroecology and food sovereignty groups". (Political Head of TU_2020)

\section{Conclusions}

The paper analyzes the EAC as a training tool for cadres of agrarian organizations in their ideological re-peasantization process. The EAC can be considered a training school that serves the LVC's educational policy, and that has been transferred to the Spanish context thanks to coordination between different organizations of the movement for food sovereignty to support the ideological re-peasantization of agrarian organizations.

In view of the literature on peasant political formation, this training tool, the EAC, reproduces and adapts the pedagogical principles of LVC's educational policy. The EAC's pedagogical project shares the philosophical and pedagogical principles of "peasant pedagogies" for the political formation of cadres, generational change, and the strengthening of the re-peasantization of LVC agrarian organizations. In other words, the EAC is conceived as a tool for the consolidation of a peasant bloc as a political subject in the struggle for hegemony, assuming peasant identity and food sovereignty as part of a counter-hegemonic proposal.

In this regard, based on a Gramscian framework of interpretation of collective political subjects and the training of organic intellectuals, the implementation of the EAC's pedagogical dynamics has been analyzed, and it has been verified how the development and strengthening of a collective and peasant union identity by the students is a constant in the pedagogical elements and dynamics found in both the encounters and the Peasant Action Plans. In the same way, the strategies for the training of the young people have been analyzed in the contents of the pro-peasant ideological proposal, it being verified that this training occurs through the Peasant Action Plans and the encounters' formal and informal forums. Finally, there has been analysis of the way in which the EAC takes advantage of and, at the same time, creates a framework of opportunity for the incorporation of young people as new local union cadres, assuming positions of responsibility in the union organizational structure.

In general terms, it has been confirmed that (1) the training space and the pedagogical dynamics generated by the EAC facilitate the students' acquisition and reinforcement of this peasant and union identity; (2) the students assimilate at least part of the contents of the "peasant" food sovereignty proposal; and (3) the incorporation of young people into union structures as new cadres is mostly achieved. Therefore, beyond the need for a specific analysis that investigates the internal dynamics of each of the local unions when implementing strategies, agendas, and narratives from the perspective of ideological repeasantization and coordination with the rest of the FSM organizations, it can be stated that the EAC is a useful tool for the training of peasant cadres in the process of the repeasantization of agrarian organizations, reinforcing their nature as a pro-peasant collective political subject.

Funding: This research received no external funding.

Institutional Review Board Statement: Not applicable.

Informed Consent Statement: Informed consent was obtained from all subjects involved in the study.

Data Availability Statement: Not applicable.

Acknowledgments: To all the organizations of the consortium, the coordinators, the teaching staff, the political heads of TU—responsible for the Peasant Action Plans, and all the students.

Conflicts of Interest: The author declares no conflict of interest. 


\section{Appendix A. Field Work Table}

Table A1. Field Work Data.

\begin{tabular}{|c|c|c|c|}
\hline Technical & People/Contexts & Cases & Dates \\
\hline \multirow{6}{*}{ Participant observation } & $\begin{array}{l}\text { Meetings of the organizing team } \\
\text { (consortium organizations and } \\
\text { coordinators) in their initial } \\
\text { definition phase. Definition of the } \\
\text { structure, pedagogical project } \\
\text { (justification, objectives, contents), } \\
\text { teaching team, student profiles, } \\
\text { financing, involvement of local } \\
\text { organizations, coordination, etc. }\end{array}$ & $\begin{array}{c}7 / 6 / 2010 \\
24 / 1 / 2011 \\
1 / 4 / 2011 \\
20 / 6 / 2011 \\
5 / 10 / 2011 \\
19 / 11 / 2011 \\
28 / 12 / 2012 \\
31 / 1 / 2013 \\
4 / 3 / 2013 \\
11-12 / 11 / 2013 \\
13 / 12 / 2013 \\
20 / 12 / 2013\end{array}$ & 2010-2013 \\
\hline & $\begin{array}{l}\text { Consortium meetings during the } \\
\text { course phase. Evaluation, } \\
\text { monitoring, content updating, } \\
\text { financing, strategy, etc. }\end{array}$ & $\begin{array}{c}21 / 1 / 2015 \\
1 / 6 / 2015 \\
13 / 7 / 2015 \\
23 / 11 / 2015 \\
1 / 6 / 2016 \\
27 / 7 / 2016 \\
20 / 09 / 2016 \\
3 / 11 / 2016 \\
3 / 2 / 2017 \\
4 / 4 / 2017 \\
7 / 2 / 2018 \\
11 / 7 / 2018 \\
12 / 9 / 2018 \\
30 / 10 / 2018 \\
16 / 1 / 2019 \\
28 / 2 / 2019 \\
21 / 3 / 2019 \\
12 / 6 / 2019 \\
9 / 7 / 2020\end{array}$ & $\begin{array}{l}\text { Course 2014, 2015, 2016, } \\
\text { 2017-2018, and 2019-2020 }\end{array}$ \\
\hline & Meetings between coordinators & $\begin{array}{l}\text { Meetings every two months and/or as the situation } \\
\text { demands }\end{array}$ & $\begin{array}{l}\text { Course 2014, 2015, 2016, } \\
\text { 2017-2018 and 2019-2020 }\end{array}$ \\
\hline & Teaching team meetings & $\begin{array}{c}\text { Preparation meetings for each course } \\
\text { Preparation meetings for each encounter } \\
\text { Meetings at each informal, on-site evaluation } \\
\text { encounter } \\
\text { Final evaluation meetings of each course }\end{array}$ & $\begin{array}{l}\text { Course 2014, 2015, 2016, } \\
\text { 2017-2018 and 2019-2020 }\end{array}$ \\
\hline & Holding encounters & $\begin{array}{l}\text { Attending least three of the four encounters of each } \\
\text { course }\end{array}$ & $\begin{array}{l}\text { Course } 2014,2015,2016, \\
2017-2018 \text { and } 2019-2020\end{array}$ \\
\hline & $\begin{array}{l}\text { Participating in the Peasant } \\
\text { Action Plans }\end{array}$ & $\begin{array}{l}\text { Tutoring two or three students per course, with a } \\
\text { single joint Peasant Action Plans or with different } \\
\text { Peasant Action Plans }\end{array}$ & $\begin{array}{l}\text { Course } 2014,2015,2016, \\
2017-2018 \text { and 2019-2020 }\end{array}$ \\
\hline \multirow{5}{*}{$\begin{array}{l}\text { Ethnographic } \\
\text { Interviews }\end{array}$} & Members of the consortium & $\begin{array}{c}\text { All the members of the consortium at different } \\
\text { junctures in the EAC's evolution }\end{array}$ & $\begin{array}{l}\text { Course } 2014,2015,2016, \\
2017-2018 \text { and 2019-2020 }\end{array}$ \\
\hline & Coordinators & $\begin{array}{l}\text { The coordinators at different junctures in the EAC's } \\
\text { evolution }\end{array}$ & $\begin{array}{l}\text { Course } 2014,2015,2016, \\
2017-2018 \text { and 2019-2020 }\end{array}$ \\
\hline & Teaching staff & $\begin{array}{c}\text { All the members of the consortium at different } \\
\text { junctures in the EAC's evolution }\end{array}$ & $\begin{array}{l}\text { Course } 2014,2015,2016, \\
2017-2018 \text { and } 2019-2020\end{array}$ \\
\hline & Students & Practically all the students in each one of the courses. & $\begin{array}{l}\text { Course 2014, 2015, 2016, } \\
\text { 2017-2018 and 2019-2020 }\end{array}$ \\
\hline & $\begin{array}{l}\text { Political heads of TU-responsible } \\
\text { for the Peasant Action Plans }\end{array}$ & $\begin{array}{l}\text { The political heads of TU of the Peasant Action Plans, } \\
\text { especially the alumni who have become responsible } \\
\text { for the Peasant Action Plan in the following courses }\end{array}$ & $\begin{array}{c}\text { Course 2014, 2015, 2016, } \\
\text { 2017-2018 and 2019-2020 }\end{array}$ \\
\hline
\end{tabular}

Participatory workshop (see Methodology File, Appendix B)
Design of a collective reflection workshop with members of the consortium, coordination, the teaching team, students and political heads of TU
Members of the consortium (7), coordination (1), teaching team (6), students (14) and political heads of TU (2)
November 2017 
Table A1. Cont.

\begin{tabular}{|c|c|c|c|}
\hline Technical & People/Contexts & Cases & Dates \\
\hline $\begin{array}{l}\text { Review of internal } \\
\text { documents }\end{array}$ & & $\begin{array}{c}\text { Review of all significant documents, minutes, } \\
\text { content proposals, evaluation proposals, budget } \\
\text { tables, etc. }\end{array}$ & $\begin{array}{l}\text { Course 2014, 2015, 2016, } \\
\text { 2017-2018 and 2019-2020 }\end{array}$ \\
\hline \multirow{5}{*}{$\begin{array}{c}\text { Preparation of } \\
\text { evaluation and } \\
\text { systematization reports }\end{array}$} & & $\begin{array}{l}\text { Drafting of reports and presentations for the } \\
\text { consortium in response to the situation and phase of } \\
\text { the EAC }\end{array}$ & $\begin{array}{l}\text { Course 2014, 2015, 2016, } \\
\text { 2017-2018 and 2019-2020 }\end{array}$ \\
\hline & & $\begin{array}{c}\text { Preparation of the minutes of coordination and } \\
\text { teaching team meetings }\end{array}$ & $\begin{array}{l}\text { Course 2014, 2015, 2016, } \\
\text { 2017-2018 and 2019-2020 }\end{array}$ \\
\hline & & $\begin{array}{c}\text { Co-author of the article "Peasant schools for food } \\
\text { sovereignty" [71] }\end{array}$ & Course 2014 \\
\hline & & $\begin{array}{l}\text { Co-author of the systematization of the first two } \\
\text { EAC courses }\end{array}$ & Course 2014 and 2015 \\
\hline & & $\begin{array}{l}\text { Author of the systematization report on the } \\
\text { Collective Reflection Workshop (November 2017) }\end{array}$ & Course 2014, 2015, 2016 \\
\hline
\end{tabular}

Compiled by author.

\section{Appendix B}

Table A2. Participatory Collective Reflection Workshop.

\section{Participatory Collective Reflection Workshop (November 2017)}

The objectives of this workshop were to gauge (1) the perception of the Escuela de Acción Campesina as a training facility, (2) the EAC's impacts on local organizations and in their territories, and (3) the organizations' demands and needs to continue strengthening their roles as political subjects through agrarian unionism, and their relationships with the other food sovereignty movement organizations.

These objectives were worked on (1) in moments of individual reflection, (2) in differentiated groups of students separated from the consortium's group of representatives, coordinators, and teaching team, and (3) in mixed groups containing all these profiles. The individual information was collected on Post-it notes. The collective agreements and personal opinions, determined by consensus, were placed on flip charts, and the information on each dynamic was presented in a plenary session to the rest of the groups to initiate the collective discussion with the whole group. In addition to the flip charts created, field notes were taken during the workshop to complement the information obtained.

\begin{tabular}{|c|c|c|}
\hline Participant Profile & $\begin{array}{c}\text { Number of Participants in the } \\
\text { Workshop }\end{array}$ & $\begin{array}{l}\text { Participants in the EAC } \\
\text { (Courses 2014, 2015, 2016) }\end{array}$ \\
\hline Students & 14 & $\begin{array}{l}11-2014 \\
12-2015 \\
17-2016\end{array}$ \\
\hline $\begin{array}{l}\text { Students with new union responsibilities } \\
\text { after passing through the EAC }\end{array}$ & 7 & $\begin{array}{l}5-2014 \\
2-2015 \\
6-2016\end{array}$ \\
\hline $\begin{array}{l}\text { Political heads of TU-responsible for the } \\
\text { Peasant Action Plans }\end{array}$ & 2 & $\begin{array}{c}9-2014 \\
19-2015 \\
12-2016\end{array}$ \\
\hline Consortium members & 7 & 9 \\
\hline EAC coordination & 2 & 3 \\
\hline Teaching staff & 7 & 7 \\
\hline
\end{tabular}

Compiled by author.

\section{References}

1. Casado Baides, B. (Coord.). Sistematización de la Experiencia Baserritik Mundura; Universidad del País Vasco: Bilbao, Spain, 2019.

2. Anderson, C.R.; Maughan, C.; Pimbert, M.P. Transformative agroecology learning in Europe: Building consciousness, skills and collective capacity for food sovereignty. Agric. Hum. Values 2019, 36, 531-547. [CrossRef]

3. Holt-Giménez, E. Linking farmers' movements for advocacy and practice. J. Peasant Stud. 2010, 37, 203-236. [CrossRef] 
4. Calvário, R. Food sovereignty and new peasantries: On re-peasantization and counter-hegemonic contestations in the Basque territory. J. Peasant Stud. 2017, 44, 402-420. [CrossRef]

5. Brown, G.W.; McLean, I.; McMillan, A. A Concise Oxford Dictionary of Politics and International Relations; Oxford University Press: Oxford, UK, 2018.

6. McMichael, P. Food Regimes and Agrarian Question; Fernwood Publishing: Black Point, NS, Canada; Practical Action Publishing: Rugby, UK, 2013.

7. Ploeg, J.D. The New Peasantries: Struggles for Autonomy and Sustainability in an Era of Empire and Globalization; Taylor and Francis: London, UK, 2009.

8. Committe on World Food Security-FAO. Coming to Terms with Terminology; CFS 2012/39/4; FAO: Rome, Italy, 2012.

9. Declaration of Nyelení. 2007. Available online: https://nyeleni.org/IMG/pdf/DeclNyeleni-en.pdf (accessed on 28 March 2021).

10. Val, V.; Rosset, P.; Zamora, C.; Giraldo, O.F.; Rocheleau, D. Agroecology and La Via Campesina, I. The symbolic and material construction of agroecology through the dispositive of "peasant-to-peasant" processes. Agroecol. Sustain. Food Syst. 2019, 43, 872-894. [CrossRef]

11. Rosset, P.; Val, V.; Barbosa, L.P.; McCune, N. Agroecology and La Via Campesina II. Peasant agroecology schools and the formation of a sociohistorical and political subject. Agroecol. Sustain. Food Syst. 2019, 43, 895-914. [CrossRef]

12. McCune, N.; Rosset, P.; Cruz Salazar, T.; Morales, H.; Saldívar, A. The long road: Rural youth, farming and agroecological formación in Central America. Mind Cult. Act. 2017, 24, 183-198. [CrossRef]

13. LVC. VIIth International Conference, La Via Campesina: Euskal Herria Declaration "We Feed Our Peoples and Build the Movement to Change the World"; LVC. 2017. Available online: https:/ /viacampesina.org/en/viith-international-conference-lavia-campesina-euskal-herria-declaration/ (accessed on 10 February 2021).

14. Edelman, M.; Borras, S. Political Dynamics of Transnational Agrarian Movements; Fernwood Publishing: Black Point, NS, Canada; Practical Action Publishing: Rugby, UK, 2016.

15. LVC. From Maputo to Jakarta: 5 Years of Agroecology in La Vía Campesina. LVC, 2013. Available online: https://viacampesina. org/en/from-maputo-to-jakarta-5-years-of-agroecology-in-la-via-campesina/ (accessed on 10 February 2021).

16. LVC. The Jakarta Call. 2013. Available online: https://viacampesina.org/en/the-jakarta-call/ (accessed on 10 February 2021).

17. LVC. Agroecología Campesina por la Soberanía Alimentaria y la Madre Tierra. Experiencias de LVC—Cuaderno de Formación No 7. LVC, 2015. Available online: https:/ /viacampesina.org/es/wp-content/uploads/sites/3/2015/11/CUADERNO\%207\%20 LVC\%20ESPANOL.compressed.pdf (accessed on 10 February 2021).

18. Sevilla, E. De la Sociología Rural a la Agroecología; Icaria: Barcelona, Spain, 2006.

19. Rosset, P.; Altieri, M.A. Agroecology: Science and Politics; Fernwood Publishing: Black Point, NS, Canada; Practical Action Publishing: Rugby, UK, 2017.

20. LVC. Policy Documents. 2009. Available online: https://viacampesina.org/en/la-via-campesina-policy-documents/ (accessed on 10 February 2021).

21. Holt-Giménez, E.; Shattuck, A. Food crises, food regimes and food movements: Rumblings of reform or tides of transformation? J. Peasant Stud. 2011, 38, 109-144. [CrossRef] [PubMed]

22. Amin, S. Food Sovereignty: A struggle for convergence in diversity. In Food Movements Unite! Strategies to Transform or Food Systems; Holt-Giménez, E., Ed.; Food First Books: Oakland, CA, USA, 2011.

23. Gramsci, A. Cuadernos de la Cárcel; Ediciones Era: Mexico City, Mexico, 1981.

24. Meek, D.; Bradley, K.; Ferguson, B.; Hoey, L.; Morales, H.; Rosset, P.; Tarlau, R. Food sovereignty education across the Americas: Multiple origins, converging movements. Agric. Hum. Values 2019, 36, 611-626. [CrossRef]

25. Holt-Giménez, E. Campesino a Campesino: Voices from Latin America's Farmer to Farmer Movement for Sustainable Agriculture; Food First: Oakland, CA, USA, 2006.

26. McCune, N.; Sánchez, M. Teaching the territory: Agroecological pedagogy and popular movements. Agric. Hum. Values 2019, 36, 595-610. [CrossRef]

27. Desmarais, A.A. The power of peasants: Reflections on the meanings of La Vía Campesina. J. Rural Stud. 2008, 24, 138-149. [CrossRef]

28. Khadse, A.; Rosset, P.; Morales, H.; Ferguson, B. Taking agroecology to scale: The zero budget natural farming peasant movement in Karnataka, India. J. Peasant Stud. 2017, 45. [CrossRef]

29. Caldart, R.S. Pedagogia do Movimento Sem Terra; Expresso Popular: Sao Paulo, Brazil, 2004.

30. Freire, P. Pedagogy of the Oppressed; Continuum International Publishing: New York, NY, USA, 2005.

31. Freire, P. Extension or Communication; The Seabury Press: New York, NY, USA, 1973.

32. CLOC-LVC. Available online: https:/ / cloc-viacampesina.net/procesos-de-formacion-que-impulsa-la-cloc-lvc/ (accessed on 20 August 2020).

33. Meek, D.; Tarlau, R. Critical Food Systems Education (CFSE): Educating for food sovereignty. Agroecol. Sustain. Food Syst. 2015, 40, 237-260. [CrossRef]

34. Meek, D. The cultural politics of the agroecological transition. Agric. Hum. Values 2016, 33, 275-290. [CrossRef]

35. McCune, N.; Rosset, P.; Cruz Salazar, T.; Saldívar Moreno, A.; Morales, H. Mediated territoriality: Rural workers and the efforts to scale out agroecology in Nicaragua. J. Peasant Stud. 2016, 44, 354-376. [CrossRef]

36. Stronzake, J. Movimientos sociales, formación política y agroecológica. Rev. Am. Lat. Mov. 2013, 487, $27-29$. 
37. Batista, A.F. Conciencia y Territorialización Contrahegemónica un Análisis de las Políticas de Formación de La Vía Campesina-América del Sur; Cultura Académica: São Paulo, Brazil, 2014.

38. Rosset, P. Epistemes Rurales y la Formación Agroecológica en La Vía Campesina. Rev. Cienc. Tecnol. Soc. 2015, 2, 4-13. [CrossRef]

39. Barbosa, L.P.; Rosset, P. Educaçao de campo e pedagogia camponesa agroecológica na América Latina: Aportes da La Via Campesina e da CLOC. Rev. Educ. Soc. 2017, 38, 705-724. [CrossRef]

40. Martínez-Torres, M.E.; Rosset, P. Diálogo de saberes in La Vía Campesina: Food sovereignty and agroecology. J. Peasant Stud. 2014, 41, 979-997. [CrossRef]

41. Muñoz, A.; McCune, N.; Reardon, J. Agroecological Formación for Food Sovereignty. ZNet Communications. 2014. Available online: https:/ / zcomm.org/znetarticle/agroecological-formacion-for-food-sovereignty/ (accessed on 15 March 2020).

42. Ribeiro, M. Pedagogia da alternância na educação rural/do campo: Projetos em disputa. Educ. Pesqui. 2008, 34, 27-45. [CrossRef]

43. Barbosa, L.P. Educação do Campo [Education for and by the countryside] as a political project in the context of the struggle for land in Brazil. J. Peasent Stud. 2016, 44, 118-143. [CrossRef]

44. LVC. Las místicas-Internal document of LVC. Accesed in an EAC Encounter. Unpublished work.

45. Korol, C. La educación popular en la batalla contra las muchas colonizaciones. In Resistencias Populares a la Recolonización del Continente; Korol, C. (Coord.), Ed.; América Libre: Buenos Aires, Argentina, 2010; pp. 345-358.

46. Laclau, E.; Mouffe, C. Hegemony and Socialist Strategy: Towards a Radical Democratic Politics; Verso: London, UK, 1985.

47. Marx, K. The Eighteenth Brumaire of Louis Bonaparte; Labor News: New York, NY, USA, 1951.

48. Thompson, E.P. The Making of the English Working Class; Penguin Books: Harlow, UK, 2013.

49. Appadurai, A. Modernity at Large: Cultural Dimensions of Globalization; University of Minnesota Press: Minneapolis, MN, USA, 1996.

50. Mannheim, K. Ideology and Utopia: An Introduction to the Sociology of Knowledge; Franklin Classic: Franklin, TN, USA, 2018.

51. Anderson, B. Imagined Communities: Reflections on the Origin and Spread of Nationalism; Verso Books: London, UK, 2016.

52. Hobsbawm, E.J.; Ranger, T.O. (Eds.) The Invention of Tradition; Cambridge University Press: Cambridge, UK, 1984.

53. Hardt, M.; Negri, A. Empire; Harvard University Press: London, UK, 2000.

54. Scott, J.C. Domination and the Arts of Resistance: Hidden Transcripts; Yale University Press: New Haven, CT, USA, 2008.

55. Gallar, D. La Construcción de la Universidad Rural Paulo Freire. Culturalismo para Una Nueva Ruralidad Campesinista; UCO: Córdoba, Spain, 2011.

56. Gallar, D.; Acosta, R. Pro-peasant Resignification of Rurality: Rural University «Paulo Freire». Rev. Dialectol. Tradic. Pop. 2015, LXIX285-LXIX304. [CrossRef]

57. Gallar, D.; Calle, A. La construcción de sujetos políticos y la agroecología: Una lucha por la vida. Boletín ECOS Fuhem 2017, 39, $14-22$.

58. Coller, X. Estudio de Casos; CIS: Madrid, Spain, 2000.

59. Hammersley, M.; Atkinson, P. Ethnography. Principles in Practice; Routledge: London, UK, 1983.

60. Bourdieu, P. The Logic of Practice; Polity Press: Cambridge, UK, 1990.

61. EAC. Proyecto educativo. Internal document of EAC. Unpublished work, 2013.

62. COAG. Available online: http:/ / www.coag.org/ quienes-somos (accessed on 20 August 2020).

63. Juventudes Agrarias. Available online: https://juventudesagrarias.org/ (accessed on 20 August 2020).

64. EHNE. Available online: https://www.ehnebizkaia.eus/ (accessed on 20 August 2020).

65. Sindicato Labrego Galego-SLG. Available online: http:/ / www.sindicatolabrego.com/ (accessed on 20 August 2020).

66. García Vilchis, A.L. Movimientos Sociales en la Lucha por la Tierra y el Territorio. Resistencias y Nuevos Imaginarios Emancipatorios: El Caso de EHNE-Bizkaia; Universidad de Puebla: Puebla, Mexico, 2014.

67. VVAA. Soberanía Alimentaria: Un Diálogo Crítico. EHNE, 2017. Available online: http://www.biodiversidadla.org/ Documentos/Soberania_alimentaria_un_dialogo_critico (accessed on 10 February 2021).

68. ARCo. Available online: http:/ / coag.coag.org/post/canales-cortos-de-comercializacion-299537 (accessed on 20 August 2020).

69. CAS. Plataforma Rural. Available online: https:/ / ong-cas.org/descargas/plataforma_rural_enlaweb_cas.pdf (accessed on 20 August 2020).

70. Holt-Giménez, E. (Ed.) Food Movements Unite! Strategies to Transform Our Food Systems; Food First Books: Oakland, CA, USA, 2011.

71. Aguado, J.; Viñas, A.; Gallar, D. Escuelas campesinas para la Soberanía Alimentaria. Soberanía Aliment. Biodivers. Cult. 2014, 16, 23-26. 